University of New Hampshire

University of New Hampshire Scholars' Repository

$10-27-2003$

\title{
Reactive nitrogen in Asian continental outflow over the western Pacific: Results from the NASA Transport and Chemical Evolution over the Pacific (TRACE-P) airborne mission
}

\author{
R. Talbot \\ University of New Hampshire, robert.talbot@unh.edu \\ Jack E. Dibb \\ University of New Hampshire, jack.dibb@unh.edu \\ Eric Scheuer \\ University of New Hampshire - Main Campus, Eric.Scheuer@unh.edu \\ Garry Seid \\ University of New Hampshire - Main Campus \\ R. S. Russo \\ University of New Hampshire
}

See next page for additional authors

Follow this and additional works at: https://scholars.unh.edu/earthsci_facpub

Part of the Atmospheric Sciences Commons

\section{Recommended Citation}

Talbot, R., et al. (2003), Reactive nitrogen in Asian continental outflow over the western Pacific: Results from the NASA Transport and Chemical Evolution over the Pacific (TRACE-P) airborne mission, J. Geophys. Res., 108, 8803, doi:10.1029/2002JD003129, D20.

This Article is brought to you for free and open access by the Earth Sciences at University of New Hampshire Scholars' Repository. It has been accepted for inclusion in Earth Sciences Scholarship by an authorized administrator of University of New Hampshire Scholars' Repository. For more information, please contact Scholarly.Communication@unh.edu. 


\section{Authors}

R. Talbot, Jack E. Dibb, Eric Scheuer, Garry Seid, R. S. Russo, S T. Sandholm, D Tan, H B. Singh, D R. Blake, N J. Blake, Elliot Atlas, G W. Sachse, C. Jordan, and Melody A. Avery 


\title{
Reactive nitrogen in Asian continental outflow over the western Pacific: Results from the NASA Transport and Chemical Evolution over the Pacific (TRACE-P) airborne mission
}

\author{
R. Talbot, ${ }^{1}$ J. Dibb, ${ }^{1}$ E. Scheuer, ${ }^{1}$ G. Seid, ${ }^{1}$ R. Russo, ${ }^{1}$ S. Sandholm, ${ }^{2}$ D. Tan,${ }^{2}$ \\ H. Singh, ${ }^{3}$ D. Blake, ${ }^{4}$ N. Blake, ${ }^{4}$ E. Atlas, ${ }^{5}$ G. Sachse, ${ }^{6}$ C. Jordan, ${ }^{6}$ and M. Avery ${ }^{6}$ \\ Received 1 November 2002; revised 22 April 2003; accepted 2 May 2003; published 31 October 2003.
}

[1] We present here results for reactive nitrogen species measured aboard the NASA

DC-8 aircraft during the Transport and Chemical Evolution over the Pacific (TRACE-P) mission. The large-scale distributions total reactive nitrogen $\left(\mathrm{NO}_{\mathrm{y} \text {,sum }}=\mathrm{NO}+\mathrm{NO}_{2}+\right.$ $\mathrm{HNO}_{3}+\mathrm{PAN}+\mathrm{C}_{1}-\mathrm{C}_{5}$ alkyl nitrates) and $\mathrm{O}_{3}$ and $\mathrm{CO}$ were better defined in the boundary layer with significant degradation of the relationships as altitude increased. Typically, $\mathrm{NO}_{\mathrm{y} \text {,sum }}$ was enhanced over background levels of $\sim 260 \mathrm{pptv}$ by 20 -to-30-fold. The ratio $\mathrm{C}_{2} \mathrm{H}_{2} / \mathrm{CO}$ had values of $1-4$ at altitudes up to $10 \mathrm{~km}$ and as far eastward as $150^{\circ} \mathrm{E}$, implying significant vertical mixing of air parcels followed by rapid advection across the Pacific. Analysis air parcels originating from five principal Asian source regions showed

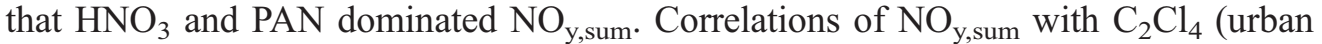
tracer) were not well defined in any of the source regions, and they were only slightly better with $\mathrm{CH}_{3} \mathrm{Cl}$ (biomass tracer). Air parcels over the western Pacific contained a complex mixture of emission sources that are not easily resolvable as shown by analysis of the Shanghai mega-city plume. It contained an intricate mixture of pollution emissions and exhibited the highest mixing ratios of $\mathrm{NO}_{\mathrm{y} \text {,sum }}$ species observed during TRACE-P. Comparison of tropospheric chemistry between the earlier PEM-West B mission and the recent TRACE-P data showed that in the boundary layer significant increases in the mixing ratios of $\mathrm{NO}_{\mathrm{y} \text {,sum }}$ species have occurred, but the middle and upper troposphere seems to have been affected minimally by increasing emissions on the Asian continent over the last 7 years. INDEX TERMS: 0365 Atmospheric Composition and Structure: Tropospherecomposition and chemistry; 0368 Atmospheric Composition and Structure: Troposphere - constituent transport and chemistry; 0322 Atmospheric Composition and Structure: Constituent sources and sinks

Citation: Talbot, R., et al., Reactive nitrogen in Asian continental outflow over the western Pacific: Results from the NASA Transport and Chemical Evolution over the Pacific (TRACE-P) airborne mission, J. Geophys. Res., 108(D20), 8803, doi:10.1029/2002JD003129, 2003.

\section{Introduction}

[2] The Transport and Chemical Evolution over the Pacific (TRACE-P) airborne mission was conducted by the National Aeronautics and Space Administration to better understand how outflow of anthropogenic emissions and crustal dust from the Asian continent affects the composition of the global atmosphere. The TRACE-P flights were designed to determine the pathways and chemical evolution of trace gases and aerosols transported to and across the

\footnotetext{
${ }^{1}$ Institute for the Study of Earth, Oceans, and Space, Climate Change Research Center, University of New Hampshire, Durham, New Hampshire, USA.

${ }^{2}$ Georgia Institute of Technology, Atlanta, Georgia, USA.

${ }^{3}$ NASA Ames Research Center, Moffett Field, California, USA.

${ }^{4}$ University of California, Irvine, Irvine, California, USA.

${ }^{5}$ National Center for Atmospheric Research, Boulder, Colorado, USA.

${ }^{6}$ NASA Langley Research Center, Hampton, Virginia, USA.

north Pacific troposphere. TRACE-P built upon the results and experience from previous NASA missions conducted in this region in 1991 and 1994, the Pacific Exploratory Missions-West A and B, respectively [Hoell et al., 1996, 1997]. Owing to the rapid industrialization on the Asian continent during the 1990s [Streets et al., 2003], TRACE-P was conducted to quantify the corresponding increase in emissions and their impact on tropospheric chemistry over the Pacific basin. The airborne mission was conducted in February-April 2001, the time period of the year characterized by the most significant outflow of pollutants and crustal dust from the Asian continent [Jacob et al., 2003]. The timing of this expedition compared to PEM-West presented an ideal situation to assess decadal changes in Asian inter-continental transport.

[3] PEM-West A was conducted in the SeptemberOctober 1991 time frame and demonstrated the complex nature of emissions over the western Pacific. For example, in the lower troposphere continental outflow was enhanced in numerous combustion and industrial tracers but at higher 
altitudes the ratio $\mathrm{C}_{2} \mathrm{H}_{2} / \mathrm{CO}$ was $<1.5$ indicating much older inputs, possibly from European origin [Talbot et al., 1996]. In the upper troposphere air parcels were enhanced in $\mathrm{CH}_{4}$ but depleted in $\mathrm{CO}_{2}$ and $\mathrm{COS}$, indicating potential biogenic emissions of $\mathrm{CH}_{4}$ and vegetative uptake of $\mathrm{CO}_{2}$ and $\mathrm{COS}$.

[4] A much more comprehensive sampling and analysis of Asian outflow was conducted during PEM-West B (1994) which revealed important subtle details. Backward 5-day isentropic trajectories and atmospheric chemistry together indicated that there was extensive rapid outflow from Asian continental areas below $5 \mathrm{~km}$ altitude [Talbot et al., 1997a, 1997b]. Aged marine air was rarely encountered over the western Pacific due to the strong late winter/ springtime continental outflow, and then it was only sampled at latitudes $<20^{\circ} \mathrm{N}$. The outflow at low altitude had significant enhancements of industrial tracers such as $\mathrm{C}_{2} \mathrm{Cl}_{4}$, $\mathrm{CH}_{3} \mathrm{CCl}_{3}$, and $\mathrm{C}_{6} \mathrm{H}_{6}$ intermixed with the combustion products $\mathrm{C}_{2} \mathrm{H}_{2}, \mathrm{C}_{2} \mathrm{H}_{6}, \mathrm{CO}$, and NO. In the middle-to-upper troposphere, Middle Eastern and European source regions were implicated as possible contributors to the outflow. The importance of vertical convective transport was apparent, with subsequent removal of water-soluble species like $\mathrm{HNO}_{3}, \mathrm{SO}_{2}$, and $\mathrm{H}_{2} \mathrm{O}_{2}$. The long-range transport of PAN in the midtroposphere with subsequent downward mixing and conversion to $\mathrm{NO}_{\mathrm{x}}$ was postulated to be an important source of reactive nitrogen to the remote Pacific boundary layer [Dibb et al., 1997].

[5] The rapid industrialization on the Asian continent is of compelling interest to atmospheric chemistry and climate change. Energy use in eastern Asia has increased by $5 \% \mathrm{yr}^{-1}$ over the past decade and is expected to continue at this rate for several more decades [U.S. Department of Energy, 1997]. Combustion of fossil fuels is the main source of energy, with emissions of $\mathrm{NO}_{\mathrm{x}}$ predicted to increase nearly five-fold by 2020 [Van Aardenne et al., 1999].

[6] The suite of NASA western Pacific missions has observed the time-dependent impact on the Northern Hemispheric tropospheric chemistry of a major industrial revolution on the Asian continent. Long-term observations from ground sites provide a continuous framework, but aircraft and satellite observations significantly augment our understanding of dynamical and chemical processes affecting atmospheric composition over a large remote geographic region like the Pacific basin. TRACE-P is the most recent NASA mission in the Pacific Rim region, and it provided a detailed chemical characterization of Asian continental outflow and emissions. In this paper we focus specifically on the suite of reactive nitrogen species, which are critical in determining the overall photochemical mixture of chemical species in continental outflow over the north Pacific. This outflow is expected to begin to influence atmospheric chemistry over North America within the current decadal time frame [Bernsten and Karlsdottir, 1999; Jacob et al., 1999].

\section{Airborne Mission}

[7] The airborne component discussed in this paper was conducted aboard the NASA Dryden DC-8 research aircraft. Transit and intensive science missions comprised 20 flights, with each one averaging $\sim 8$ hours in duration and covering an altitude range of $0.3-12.5 \mathrm{~km}$. The flights over the western Pacific, from which the data for this paper are drawn, were centered in the region west of $150^{\circ} \mathrm{E}$ longitude. The base of operations for these flights was from Hong Kong (seven missions) and Yokota, Japan (five missions).

[8] The overall scientific rationale and description of the individual aircraft missions are described in the TRACE-P overview paper [Jacob et al., 2003]. The features of the large-scale meteorological regime and associated air parcel backward trajectory analyses for the February-March 2001 time frame are presented by Fuelberg et al. [2003]. A general description of the chemical composition of the Asian continental outflow is in a companion paper [Russo et al., 2003]. The focus of that paper is primarily $\mathrm{CO}, \mathrm{O}_{3}$, and hydrocarbons, with minimal discussion of the $\mathrm{NO}_{\mathrm{y}}$ family. The purpose of this paper is to fill that gap and provide more detail that can be addressed in a general discussion of continental outflow.

[9] We present here a broad description of the outflow chemistry focused on the reactive nitrogen family and refer to the overview paper [Jacob et al., 2003] and companion papers for descriptions of the various measurements. Additionally, more specific information is included below for measurement details of the reactive nitrogen species. Since total reactive nitrogen $\left(\mathrm{NO}_{\mathrm{y}}\right)$ was not measured on the DC-8, we use the sum of $\mathrm{NO}, \mathrm{NO}_{2}, \mathrm{PAN}, \mathrm{HNO}_{3}$, and $\mathrm{C}_{1}-\mathrm{C}_{5}$ alkyl nitrates to represent $\mathrm{NO}_{\mathrm{y}}\left(\mathrm{NO}_{\mathrm{y} \text {,sum }}\right)$. Aerosol nitrate and PPN were not included in $\mathrm{NO}_{\mathrm{y} \text { sum }}$ since their contribution to $\mathrm{NO}_{\mathrm{y} \text {,sum }}$ rarely exceeded $5 \%$ and $1 \%$, respectively, and because in the case of nitrate its measurement time base $(\sim 10 \mathrm{~min})$ was substantially longer than that for gas phase species. In general, the agreement between $\mathrm{NO}_{\mathrm{y} \text {,sum }}$ and $\mathrm{NO}_{\mathrm{y}}$ measured with a gold catalytic converter is $\sim 20 \%$ for the suite of TRACE-P instruments and $\mathrm{NO}_{\mathrm{y}}$ mixing ratios in the range 100-3000 pptv [Talbot et al., 1999].

[10] $\mathrm{NO}$ and $\mathrm{NO}_{2}$ were measured by the Georgia Institute of Technology using photofragmentation two-photon laserinduced fluorescence (TP-LIF) [Sandholm et al., 1990]. The method spectroscopically detects NO, with UV laser photolysis of $\mathrm{NO}_{2}$ and subsequent detection of NO. The optical detection scheme involves sequentially exciting rotationally resolved transitions in the $X^{2} I I-A^{2} \sum$ and the $A^{2} \sum-$ $\mathrm{D}^{2} \sum$ bands of $\mathrm{NO}$ using laser wavelengths centered at 226 $\mathrm{nm}$ and $1.1 \mu \mathrm{m}$, respectively. The resulting blue shift in fluorescence is monitored near $190 \mathrm{~nm}$. Calibration utilized a NIST certified NO standard $( \pm 1-2 \%)$. The overall uncertainty of the measurements is estimated to be on the order of 20-30\% [Eisele et al., 2003]. The sampling inlet was comprised of a $10 \mathrm{~cm}$ ID glass-coated (vapor-deposited) intake flowing by ram force at $\sim 6 \times 10^{3} \mathrm{~cm} \mathrm{~s}^{-1}$, giving a residence time of $40 \mathrm{~ms}$. The details of the entire system are described by Bradshaw et al. [1999].

[11] PAN was measured by NASA Ames Research Center using cryogenic preconcentration of ambient air and analysis of it using gas chromatography with electron capture detection. PAN was measured every 5 min aboard the DC- 8 by an electron-capture gas-chromatographic technique [Singh et al., 2001]. Typically, $160 \mathrm{ml}$ of ambient air was preconcentrated at $-140^{\circ} \mathrm{C}$ over a 2 -min period. PAN calibrations were performed by using a 2-ml diffusion tube filled with pure liquid PAN in an $n$-tridecane matrix. A dynamic dilution system was used to generate low-pptv mixing ratios of PAN. The technique has a measurement 
sensitivity of better than 1 pptv PAN. Instrument precision and accuracy are estimated to be $\pm 10 \%$ and $\pm 25 \%$, respectively. Intercomparison studies performed during TRACE-P further confirmed that the reliability of the PAN measurements was within these specifications [Eisele et al., 2003].

[12] Nitric acid was measured by the University of New Hampshire using the mist chamber/ion chromatography technique [Talbot et al., 2000]. Sampling was conducted using a high-flow manifold (3000 liters per min) that was glass-coated (vapor-deposited) and heated to $50^{\circ} \mathrm{C}$. The manifold was $8 \mathrm{~cm}$ ID and had a diffuser configuration over the entrance to boost the flow/pressure and facilitate sampling at the high velocities (Mach 0.88 ) of the DC-8. The inlet design was nearly identical to that used for $\mathrm{NO} /$ $\mathrm{NO}_{2}$ [Bradshaw et al., 1999] and $\mathrm{OH} / \mathrm{HO}_{2}$ [Brune et al., 1998]. The inlet was equipped with the capability to conduct standard additions of $\mathrm{HNO}_{3}$ into the manifold and quantify its passing efficiency frequently during flight. A permeation source was used for $\mathrm{HNO}_{3}$ from which the output was tracked using Nylon filters and a $\mathrm{NO}_{\mathrm{x}}$ chemiluminescence instrument equipped with a molybdenum $\mathrm{NO}_{\mathrm{y}}$ converter heated to $350^{\circ} \mathrm{C}$. The output of the permeation source was about 200 ppbv of $\mathrm{HNO}_{3}$ that could be readily diluted to pptv levels and quantified in our manifold. Thus standard additions were conducted at approximately twice ambient $\mathrm{HNO}_{3}$ mixing ratios. The precision and accuracy of the $\mathrm{HNO}_{3}$ measurements are both in the range of $10-20 \%$ depending on the ambient mixing ratio. The time resolution of the ambient measurements was two minutes. Inter-comparisons with a chemical ionization mass spectrometer instrument aboard the NASA P-3 aircraft during TRACEP showed good agreement $( \pm 20 \%)$ under most atmospheric conditions [Eisele et al., 2003].

[13] Alkyl nitrate species were measured by the University of California, Irvine and the National Center for Atmospheric Research (NCAR) after collection of ambient air samples in 2-liter electropolished stainless steel canisters. A two-stage metal bellows pump was used to pressurize the canisters to $3.8 \mathrm{hPa}$. Samples were obtained every 3-7 min during horizontal flight legs with a collection interval of $8 \mathrm{~s}$ at $150 \mathrm{~m}$ to $90 \mathrm{~s}$ at $12 \mathrm{~km}$. The following alkyl nitrates were measured in each sample: methyl nitrate $\left(\mathrm{CH}_{3} \mathrm{ONO}_{2}\right)$, ethyl nitrate $\left(\mathrm{C}_{2} \mathrm{H}_{5} \mathrm{ONO}_{2}\right)$, n-propyl nitrate $\left(\right.$ n- $\left.\mathrm{C}_{3} \mathrm{H}_{7} \mathrm{ONO}_{2}\right)$, i-propyl nitrate $\left(\mathrm{i}-\mathrm{C}_{3} \mathrm{H}_{7} \mathrm{ONO}_{2}\right)$, 2-butyl nitrate $\left(2-\mathrm{C}_{4} \mathrm{H}_{9} \mathrm{ONO}_{2}\right)$, 2-pentyl nitrate $\left(2-\mathrm{C}_{5} \mathrm{H}_{11} \mathrm{NO}_{3}\right)$, and 3-pentyl nitrate $\left(3-\mathrm{C}_{5} \mathrm{H}_{11} \mathrm{NO}_{3}\right)$. The analytical procedures are detailed by Colman et al. [2001]. The $\mathrm{C}_{1}-\mathrm{C}_{5}$ alkyl nitrates were separated using three of the five columndetector combinations in the UC-Irvine laboratory. The limit of detection for alkyl nitrates was typically $0.02 \mathrm{pptv}$ with a precision of $\pm 5 \%$ at mixing ratio $>5$ pptv and $\pm 10 \%$ below 5 pptv. Calibration for alkyl nitrates used regular analysis of whole air standards which were intercalibrated with synthetic air standards prepared at NCAR. Analysis of duplicate samples and standards by both laboratories agreed within $\pm 2 \%$.

\section{General Trends Over the Western Pacific}

[14] To present the overall distribution of reactive nitrogen over the western Pacific, the entire $1 \mathrm{~min}$ data set for flights 6-17 was utilized. For species with a time response greater than $1 \mathrm{~min}$, duplicated values generated by the merging process were removed from the database. Data collected above $7 \mathrm{~km}$ altitude was filtered additionally to remove stratospheric air influences using $\mathrm{O}_{3}(>120 \mathrm{ppbv}), \mathrm{CO}$ $(<70 \mathrm{ppbv})$, and dew point temperature $\left(<-50^{\circ} \mathrm{C}\right)$ values indicative of stratospheric influence. However, the air parcels in this region often had both combustion and stratospheric influences superimposed, so it was impossible to completely remove the stratospheric component. The data set we used has some higher values of $\mathrm{O}_{3}$ while the mixing ratios of other species such as $\mathrm{CO}$ were quite elevated. We only removed the most strongly influenced stratospheric cases.

[15] The latitudinal distributions of $\mathrm{NO}_{\mathrm{y}, \text { sum }}$ and $\mathrm{CO}$ are presented in Figure 1, and they illustrate the widespread influence of combustion emissions on atmospheric chemistry over the western Pacific. The close correspondence in the

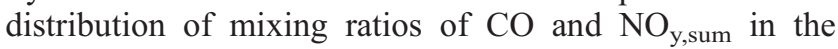
heavily polluted plumes suggests a direct source relationship between combustion and reactive nitrogen species. Indeed, at all altitudes in the latitudinal band of $20-40^{\circ} \mathrm{N}$ well-defined plumes contained $\mathrm{NO}_{\mathrm{y} \text {,sum }}$ in excess of 1000 pptv. However, as shown later in this paper, outside the few large plumes the general correspondence between $\mathrm{CO}$ and $\mathrm{NO}_{\mathrm{y} \text {,sum }}$ is not readily apparent (they are largely uncorrelated).

[16] The relationship between $\mathrm{NO}_{\mathrm{y} \text {,sum }}$ and $\mathrm{CO}$ is shown in Figure 2. The correspondence in $\mathrm{NO}_{\mathrm{y} \text {,sum }}$ and $\mathrm{CO}$ was most apparent in the boundary layer and was not well defined at altitudes above it. Presumably this reflects sampling of less processed air parcels down low and the close proximity of major emission sources on the Asian continent. Even in the boundary layer the relationship between $\mathrm{NO}_{\mathrm{y} \text {,sum }}$ and $\mathrm{CO}$ was strongly driven by sampling of heavily polluted plumes advected over the Pacific Rim region from concentrated urban centers such as Shanghai. At higher altitudes the air parcels had undergone more processing, and they are also likely impacted by both Asian and other more distant sources. For example, a European influence was hypothesized for altitudes $>7 \mathrm{~km}$ over the western Pacific during the PEM-West B time frame [Talbot et al., 1997a]. However, for TRACE-P the European influence above $7 \mathrm{~km}$ appears to have been minimal based on three-dimensional (3-D) model results [Liu et al., 2003].

[17] Photochemical processing of air parcels that have $\mathrm{NO}_{\mathrm{x}}$-rich hydrocarbon mixtures leads to production of a suite of reactive nitrogen compounds and $\mathrm{O}_{3}$. Thus the correspondence between $\mathrm{NO}_{y, \text { sum }}$ and $\mathrm{O}_{3}$ is of interest. In general, the correlations between $\mathrm{NO}_{y}$,sum and $\mathrm{O}_{3}$ were poorly defined in the Asian outflow over the western Pacific (Figure 2). As in the case of $\mathrm{CO}$, the tightest relationship was found in the boundary layer, where it was again determined largely by the most heavily polluted plumes. In the midtroposphere the values were centered on an $\mathrm{O}_{3}$ mixing ratio of $60 \mathrm{ppbv}$, with $\mathrm{NO}_{\mathrm{y}, \text { sum }}$ being as high as 2500 pptv. Observations very similar to these reported here were obtained during PEM-West $\mathrm{B}$, except that it was centered on $\mathrm{O}_{3}$ mixing ratios in the $40-50$ ppbv range [Koike et al., 1997]. Above $7 \mathrm{~km}$ altitude there was a weak linear trend in $\mathrm{NO}_{\mathrm{y} \text {,sum }}$ and $\mathrm{O}_{3}$ that may be related to the strong linear correspondence between these species (i.e., $\mathrm{HNO}_{3}$ and $\mathrm{O}_{3}$ ) in stratospheric air [e.g., Talbot et al., 1997b]. As stated earlier, air parcels in this region were 

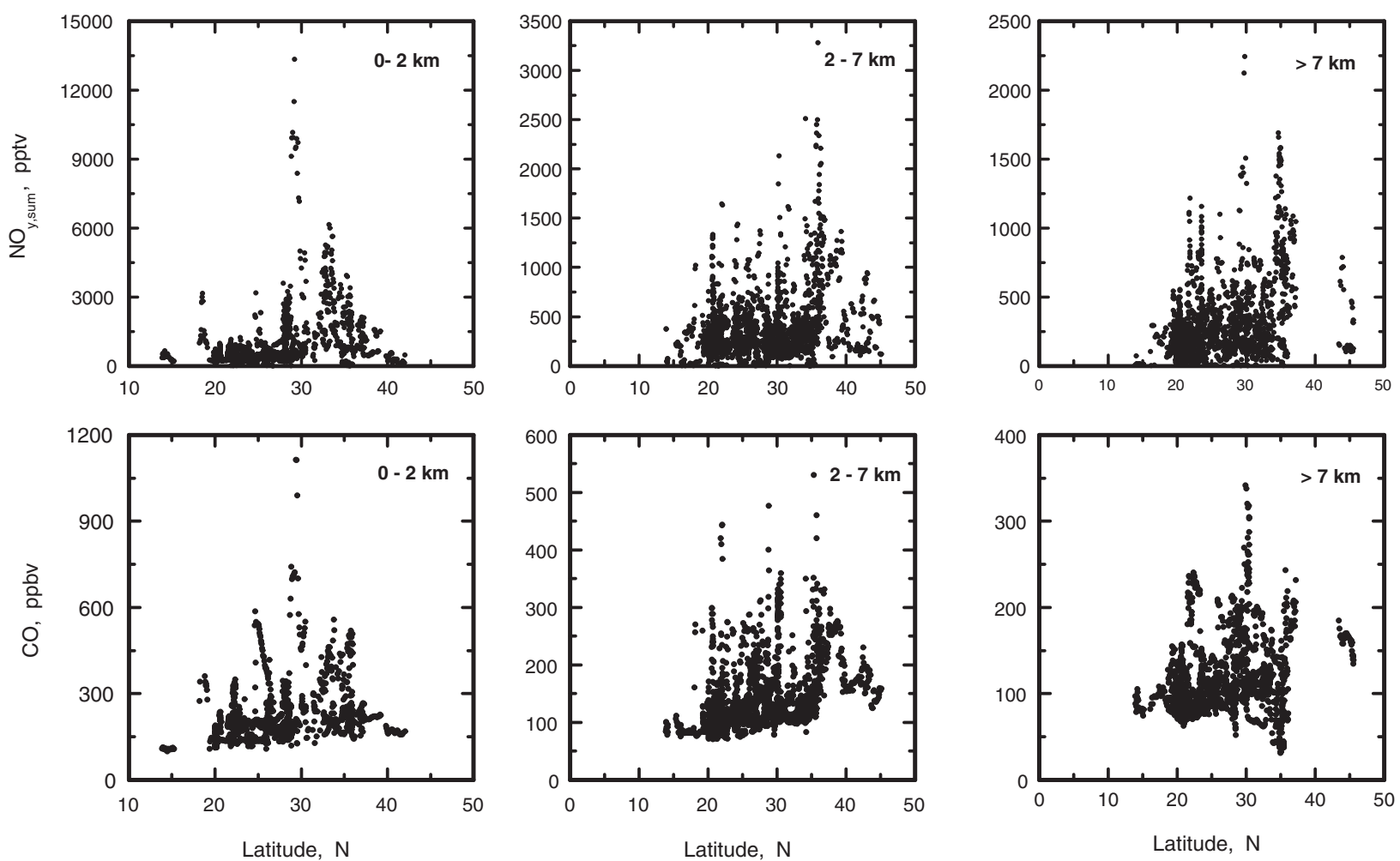

Figure 1. Latitudinal distribution of mixing ratios of $\mathrm{NO}_{\mathrm{y}}$ and $\mathrm{CO}$ over the western Pacific west of $150^{\circ} \mathrm{E}$ longitude. Data is shown for three altitude bins of $0-2,2-7$, and $>7 \mathrm{~km}$.
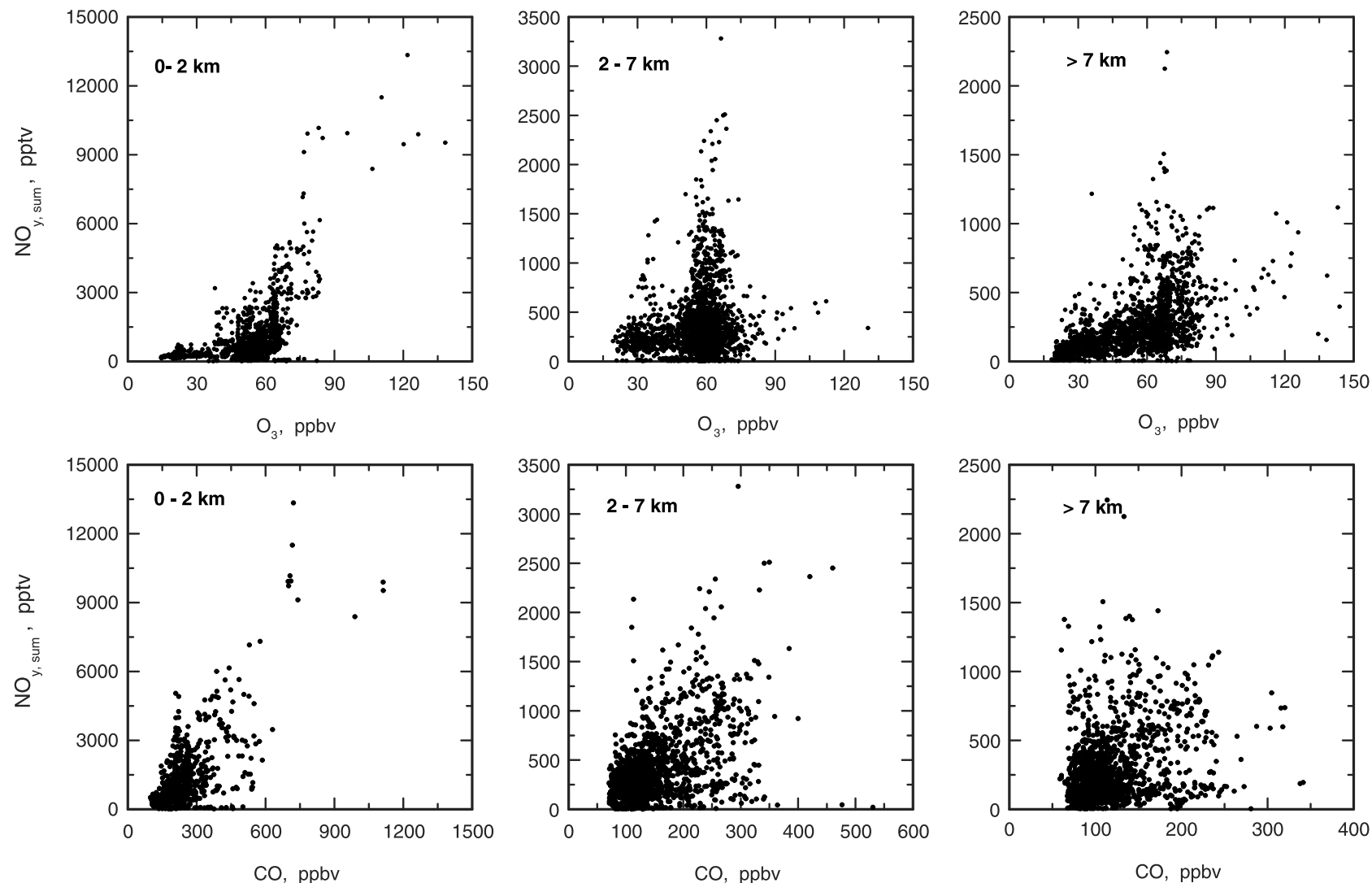

Figure 2. Relationships between mixing ratios of $\mathrm{NO}_{\mathrm{y}}$ and $\mathrm{CO}$ or $\mathrm{O}_{3}$ in three altitude bins of $0-2,2-7$, and $>7 \mathrm{~km}$ 

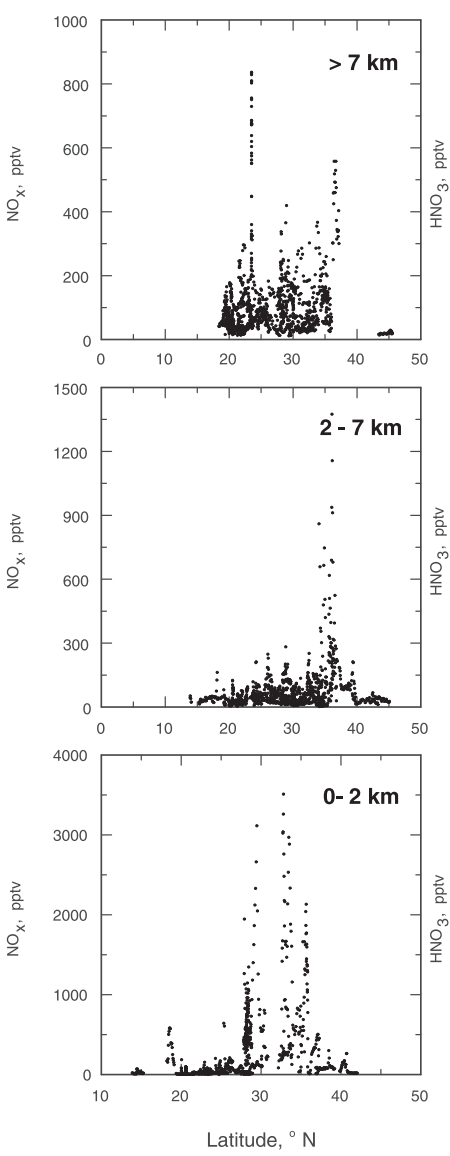
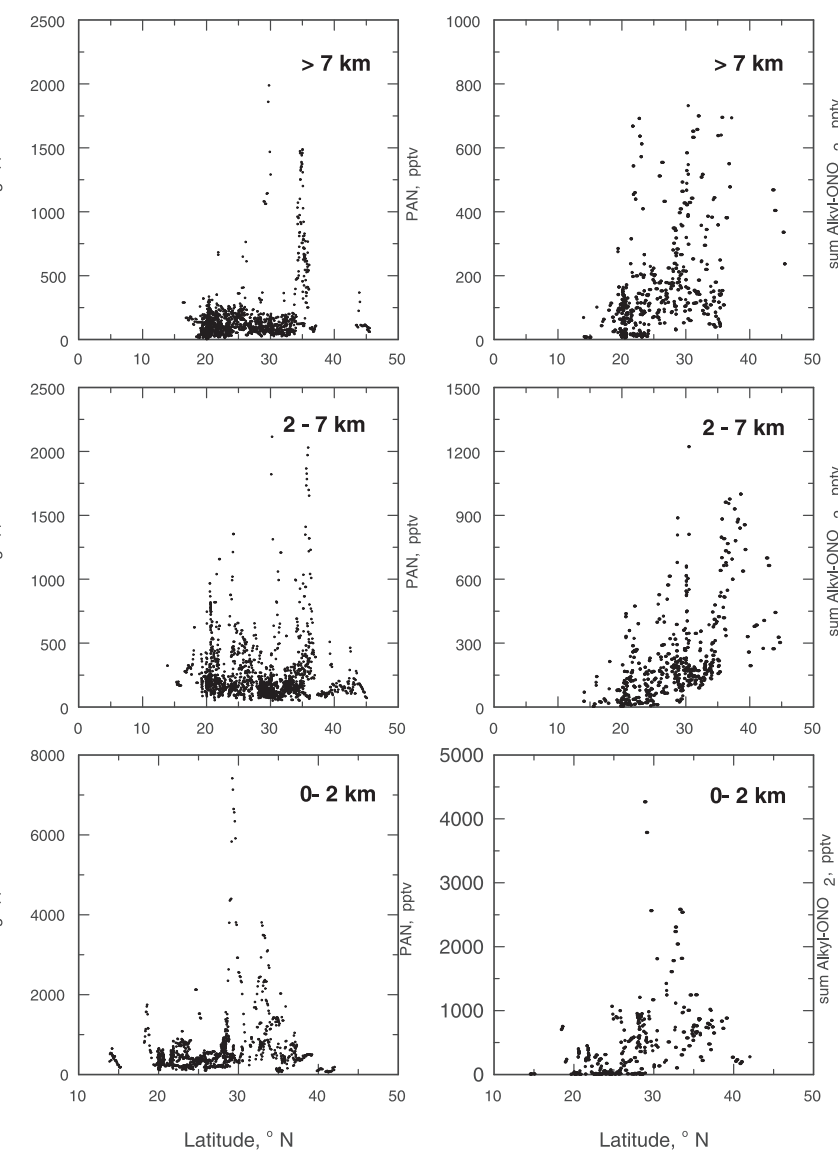
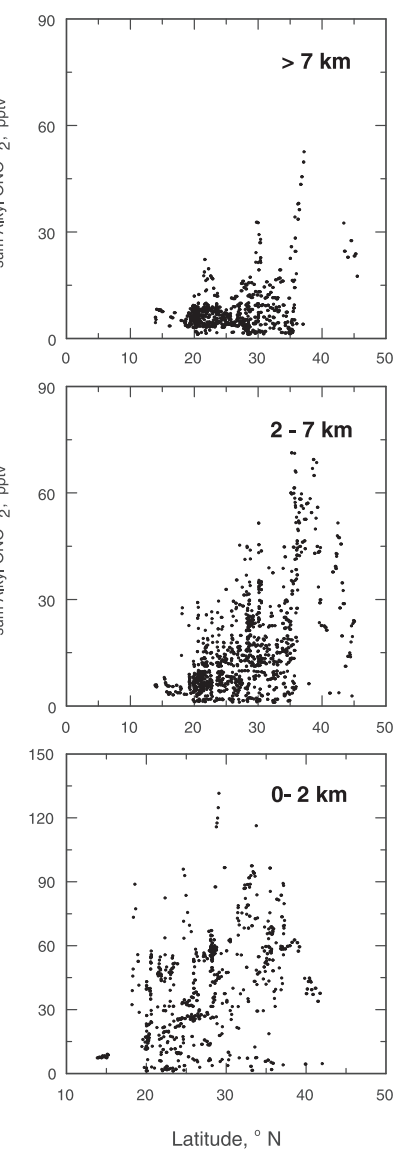

Figure 3. Latitudinal distribution of individual NOy species in three altitude bins of $0-2,2-7$, and $>7 \mathrm{~km}$.

influenced coincidently by combustion and stratospheric sources which could not be separated adequately. Alternatively, the positive correlation could have been the result of biomass burning emissions occurring in southeastern Asia. This point is addressed further in this paper when we examine specific characteristics of various Asian source regions based on analysis of air parcel backward trajectories.

[18] The latitudinal pattern of individual reactive nitrogen species over the western Pacific is presented in Figure 3. For the most part, mixing ratios of $\mathrm{NO}_{\mathrm{x}}$ were $<100$ pptv, suggesting that the sampled air parcels were aged at least 1-2 days which allowed for transformations of it to $\mathrm{HNO}_{3}$, PAN, and other $\mathrm{NO}_{\mathrm{y} \text {,sum }}$ species. The largest enhancements in all species occurred at $30^{\circ} \mathrm{N}$ when the DC- 8 sampled the Shanghai mega-city urban plume during a boundary layer leg over the Yellow Sea. This plume contained mixing ratios of $\mathrm{NO}_{\mathrm{x}}, \mathrm{HNO}_{3}, \mathrm{PAN}$, and alkyl nitrates of up to 3,000 , $8,000,4,300$, and $225 \mathrm{pptv}$, respectively. In a later section of this paper we discuss the chemical composition of this plume in detail.

[19] The vertical distribution of reactive nitrogen species provides insight to the nature of their sources, and in particular the association of origin either on the Asian continent or from long-range transport into the western Pacific region. These distributions are summarized in Figure 4, where the alkyl nitrate species are represented as the sum of the individual species (i.e., sum Alkyl-ONO ${ }_{2}$ ). Shown also is aerosol nitrate based on Teflon filter measurements with approximately 10 min time resolution as described by Dibb et al. [2003].

[20] All the gas phase reactive nitrogen species showed significant deviations and enhancements well above their background values, defined as the median of the lowest $15 \%$ of the observed mixing ratios at a given altitude. The background mixing ratios exhibited little altitude dependence, and representative values were as follows: $\mathrm{NO}_{\mathrm{x}}$ (25 pptv), $\mathrm{HNO}_{3}$ (125 pptv), PAN (100 pptv), alkyl nitrates (7 pptv), aerosol nitrate (25 pptv), and $\mathrm{NO}_{\mathrm{y}, \text { sum }}(257 \mathrm{pptv})$. The enhancements occurred at all altitudes up to the $12 \mathrm{~km}$ ceiling of the DC-8 aircraft. It was not uncommon for the enhanced mixing ratios to be 10-to-20-fold larger than their corresponding background value. The greatest enhancement generally occurred in the boundary layer indicating the predominance of surface sources in Asia on regional tropospheric chemistry. Particularly noteworthy were the alkyl nitrate species which exhibited combined increases of up to $50 \mathrm{pptv}$ at altitudes up to $8 \mathrm{~km}$. The alkyl nitrate distribution was dominated by 2-butyl nitrate which comprised on average $30 \%$ of the sum depicted in Figure 4. In general, the vertical distributions indicate a strong surface source for $\mathrm{NO}_{\mathrm{y} \text {,sum }}$ species with a strong influence up to $10 \mathrm{~km}$ altitude. We argue later in this paper that based on $\mathrm{C}_{2} \mathrm{H}_{2} /$ $\mathrm{CO}$ ratios of 1-4 these enhancements reflect fairly recent Asian emissions rather than influence from long-range transport. 

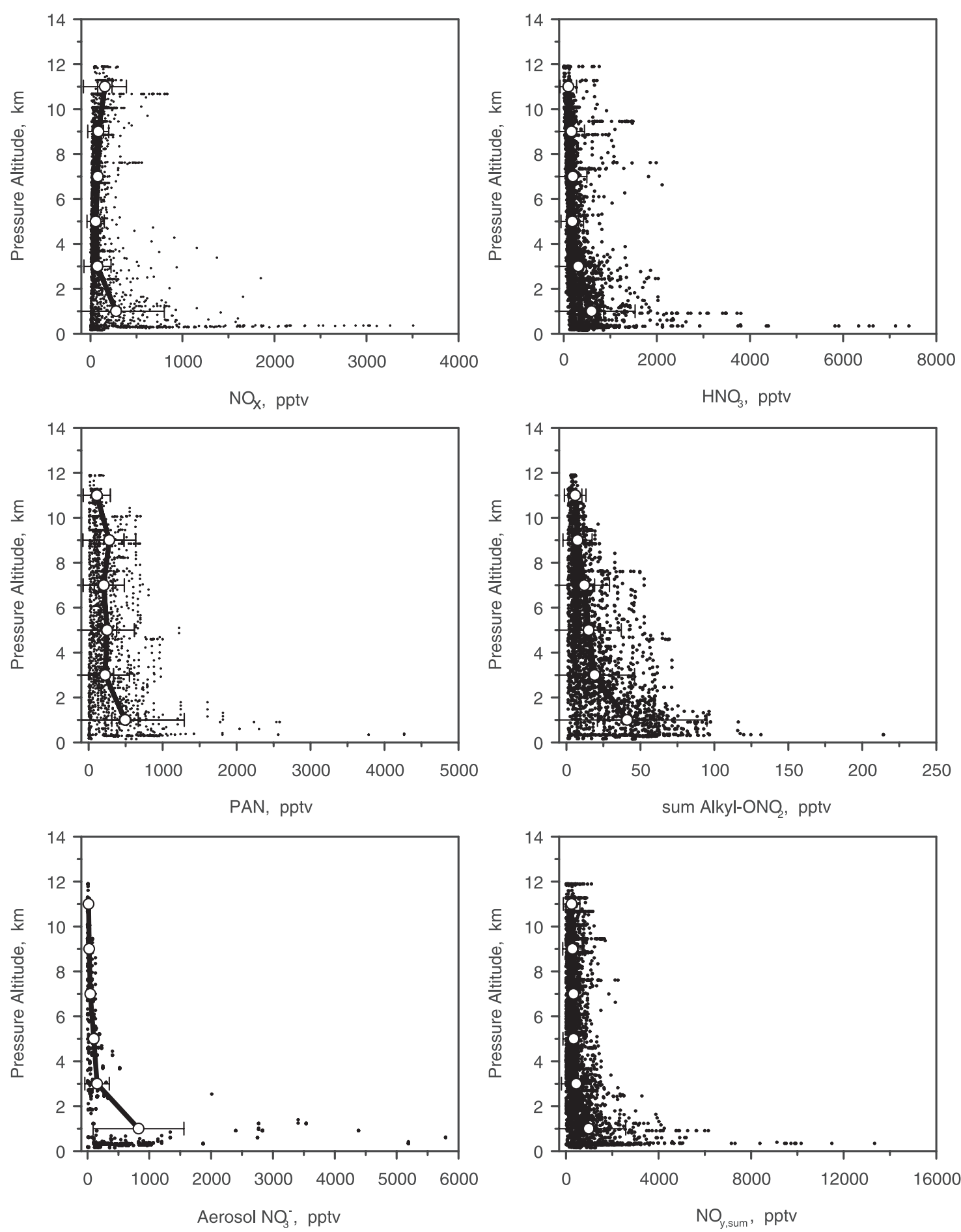

Figure 4. Vertical distribution of individual $\mathrm{NO}_{\mathrm{y}}$ species over the western Pacific west of $150^{\circ} \mathrm{E}$ longitude. The open circles represent the mean value with one standard deviation indicated by the horizontal bar for two km thick altitude bins.

[21] The largest mixing ratios of aerosol nitrate were observed in the Asian coastal marine boundary layer. On some occasions ppbv values of aerosol nitrate were measured that far exceeded attendant mixing ratios of $\mathrm{HNO}_{3}$. Undoubtedly, the high levels of nitrate reflected uptake of $\mathrm{HNO}_{3}$ by sea salt aerosols, as evidenced by coincidently large mixing ratios of sodium and chloride [Dibb et al., 2003; Jordan et al., 2003].
[22] An important consideration for interpretation of the TRACE-P observations is the relative processing of air parcels over various spatial and temporal scales. Here we use the ratio $\mathrm{C}_{2} \mathrm{H}_{2} / \mathrm{CO}$ as a scaling factor in this regard since it is unaffected by physical removal processes. The ratio is decreased over time by chemical attack by $\mathrm{OH}$ (i.e., $\mathrm{C}_{2} \mathrm{H}_{2}$ lifetime about 2 weeks compared with $\mathrm{CO}$ of several months) and physical mixing processes. The distribution 

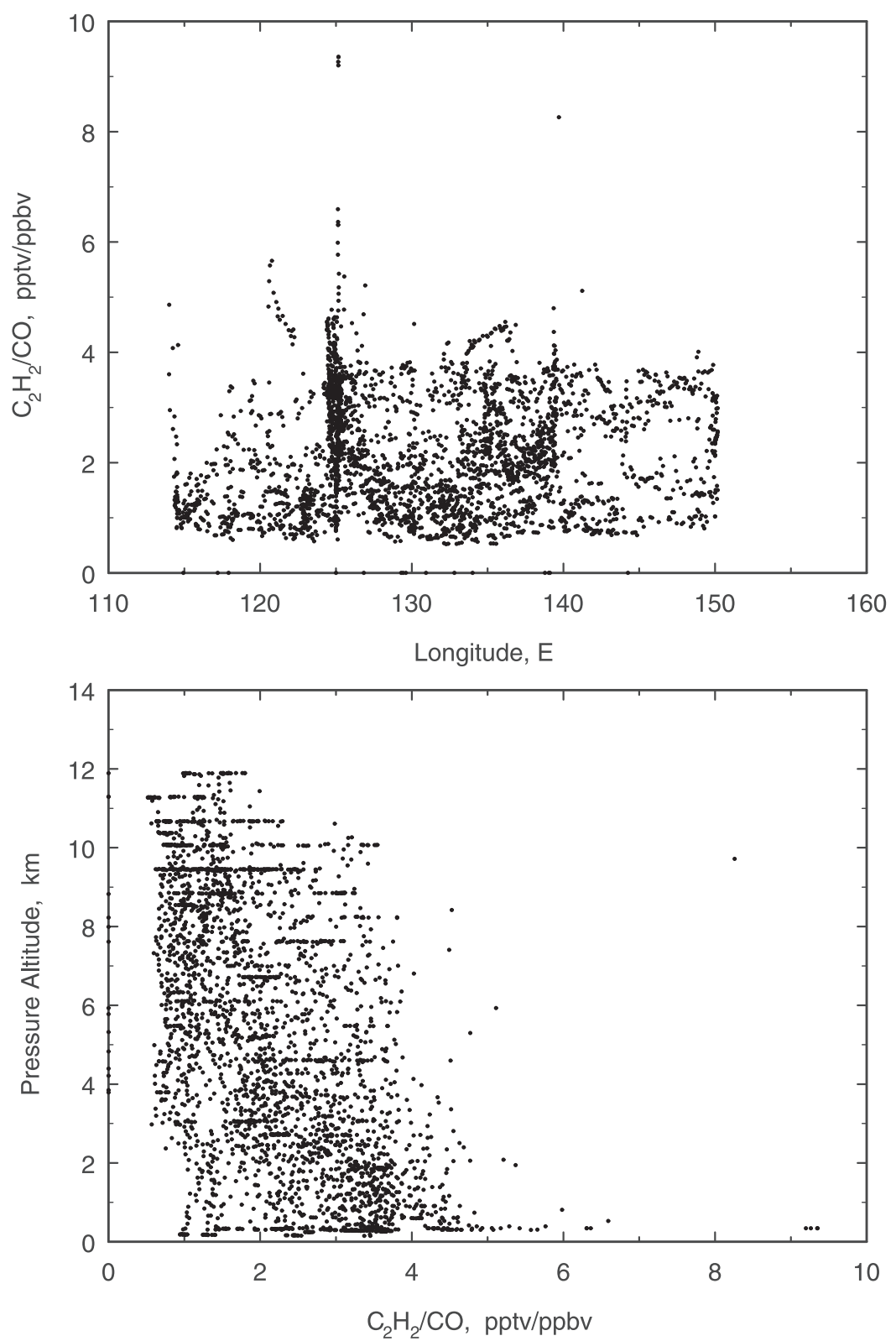

Figure 5. Vertical and longitudinal distributions of the $\mathrm{C}_{2} \mathrm{H}_{2} / \mathrm{CO}$ ratio over the western Pacific west of $150^{\circ} \mathrm{E}$ longitude.

of the values of this ratio over the western Pacific provides key insight into transport and mixing processes on various time scales. Values $>1$ indicate fairly recent emissions $(<5$ days $)$ while ratios $<1$ indicate extensively processed air by mixing and chemical decomposition.

[23] The vertical altitudinal ensemble of values in $\mathrm{C}_{2} \mathrm{H}_{2}$ / $\mathrm{CO}$ is presented in Figure 5 along with the longitudinal variation. The distributions are striking; ratio values in the middle-to-upper troposphere mimic the boundary layer and also indicate transport of continent emissions across the Pacific. Further, the data suggest that frontal uplifting and vertical transport must be rapid and operating continuously over the Asian continent in combination with extensive westerly transport of pollutants at all altitudes. The travel distances and timing implied by the backward trajectories suggest the uplifting and vertical transport must be occur- ring on the time scale of hours. A more detailed analysis is needed to better constrain these various transport rates. These results explain the blurred correlations between $\mathrm{NO}_{y, \text { sum }}$ and $\mathrm{CO}$ or $\mathrm{O}_{3}$. The continuous intermixing of air parcels of various ages and processing would lead directly to very complex distributions and relationships of $\mathrm{NO}_{\mathrm{y}, \mathrm{sum}}$, $\mathrm{CO}$, and $\mathrm{O}_{3}$ over the western Pacific, which is exactly what we observed. This same picture was captured by the observation-based climatologies developed by Emmons et al. [2000]. For the western Pacific the model simulations for the PEM-West field campaigns showed the same vertical patterns and mixing ratios observed during TRACE-P for $\mathrm{O}_{3}, \mathrm{CO}$, and $\mathrm{NO}_{\mathrm{x}}$, but deviations were up to two-fold for $\mathrm{HNO}_{3}$ and PAN. The model predicted ratios of PAN/NO and $\mathrm{HNO}_{3} / \mathrm{NO}_{\mathrm{x}}$ were 2-3 times higher than observations in the $2-8 \mathrm{~km}$ altitude range, indicating the difficulty in 


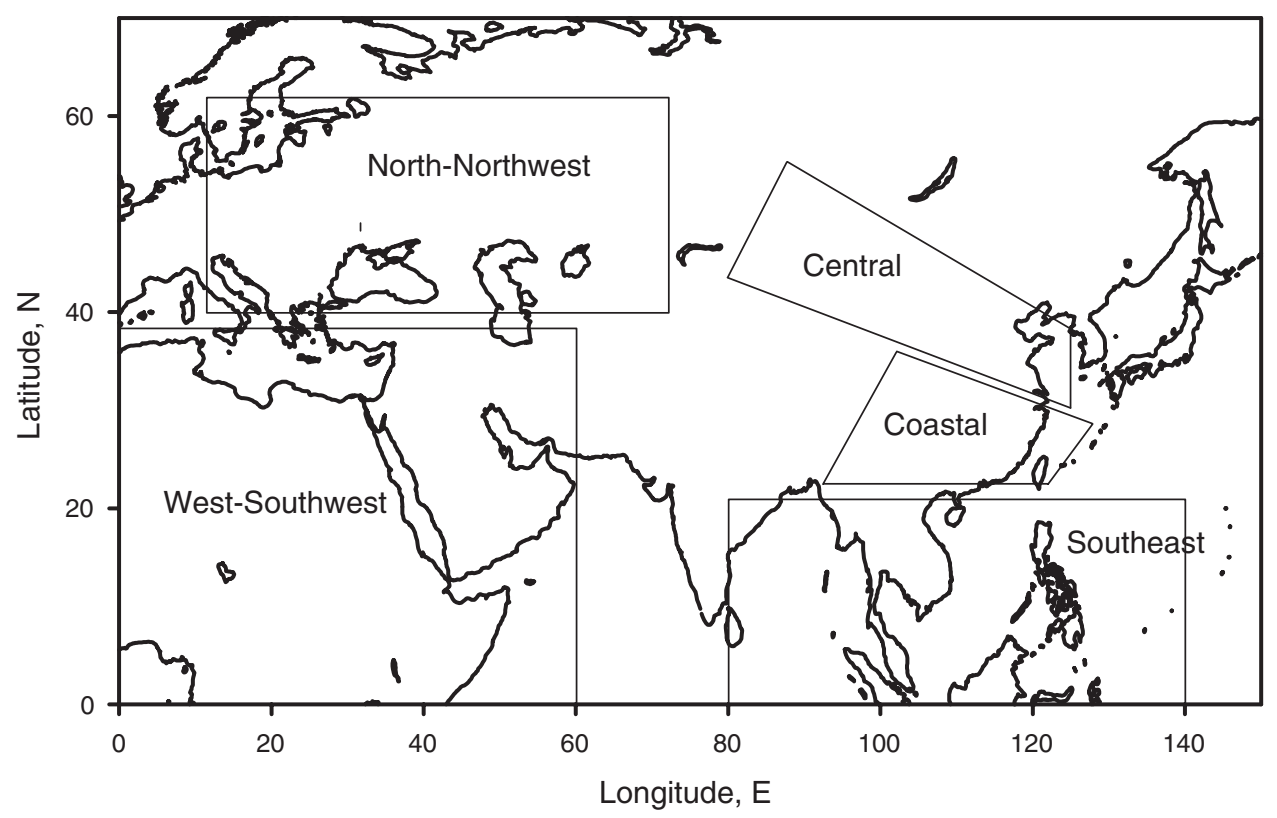

Figure 6. Geographic representation of the five principal source regions on the Asian continent determined from analysis of air parcel isentropic backward trajectories.

estimating the degree of air mass processing and interconversion of $\mathrm{NO}_{\mathrm{y}}$ species.

[24] An important transport pattern over Asia during winter is bifurcation of westerly flow when it passes over the Tibetan Plateau. Here the northern branch forms many blocked anticyclones while the southern one forms many troughs or cut-off lows, such as the Bangladesh trough and other troughs in southern China. The two branches merge at the eastern edge of the Plateau, resulting in strong winds over the southern Sea of Japan, where the maximum wind speed can reach over $70 \mathrm{~m} \mathrm{~s}^{-1}$ at $500 \mathrm{mb}$ [Zhang, 1992]. Such a dynamic system is conducive to the occurrence of unstable weather systems in southern China in winter. The associated dynamical processes help explain why the TRACE-P data show pollutants mixed to high altitudes and transported eastward rapidly to $150^{\circ} \mathrm{E}$.

\section{Relationships Based on Source Region Apportionments}

[25] To examine the detailed relationships of $\mathrm{NO}_{\mathrm{y}, \text { sum }}$ species with source tracer species and their spatial variability, air parcel backward trajectories were used to establish the principal source region locations on the Asian continent. Isentropic backward trajectories were provided by Florida State University for TRACE-P, and a description of the method is provided in Fuelberg et al. [2003]. For consistency with other TRACE-P analyses, we adopted the source region designations in this paper determined by Russo et al. [2003] and Jordan et al. [2003]. Five regions were identified in their analyses as depicted in Figure 6. These were classified as follows: (1) north-northwest (NNW), (2) westsouthwest (WSW), (3) southeast Asia (SE Asia), (4) coastal and, (5) central. The major urban/industrial centers in China are located within the coastal and central source regions.

[26] Since we have introduced the general latitudinal and vertical distributions of reactive nitrogen species for the western Pacific region, more specific source region relationships are presented here. We begin with the altitudinal budget of $\mathrm{NO}_{\mathrm{y} \text {,sum }}$ species in air masses with backward trajectories from the various source regions (Figure 7). In the southeast and coastal groups, $\mathrm{HNO}_{3}$ dominated $\mathrm{NO}_{\mathrm{y} \text {,sum }}$ in the boundary layer and midtroposphere. This was especially true for the coastal group where $\mathrm{HNO}_{3}$ comprised

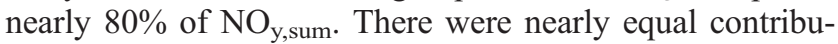
tions from $\mathrm{HNO}_{3}$ and PAN in the other three source regions, with PAN favored in the NNW and WSW groups at all altitudes. These distributions are consistent with expectations of less PAN in warmer locations due to its thermal instability and more PAN at higher altitudes where it is more stable. The predominance of $\mathrm{HNO}_{3}$ and PAN in the $\mathrm{NO}_{\mathrm{y}, \text { sum }}$ budget indicates that the majority of sampled air parcels were aged several days with significant photochemical processing over that time interval. It is not clear why $\mathrm{NO}_{\mathrm{x}}$ comprised $20-25 \%$ of $\mathrm{NO}_{\mathrm{y} \text {,sum }}$ in the middle to upper troposphere in the WSW group. This finding was quite different than in the other four groups where its contribution was $<10 \%$. Possibilities include recent inputs from sources such as biomass burning, lightning, and stratospheric inputs or decreased photochemical activity (i.e., less efficient conversion to other $\mathrm{NO}_{\mathrm{y} \text {,sum }}$ species).

[27] Together these data indicate that significant outflow of reactive nitrogen occurs at all altitudes from the Asian continent with much of it residing in the reservoir species PAN. Owing to its long lifetime in the middle and upper troposphere, it can subsequently carry reactive nitrogen over long distances and be a source of $\mathrm{NO}_{\mathrm{x}}$ to various areas of the Northern Hemisphere troposphere. During PEM-West B strong outflow in the mid-troposphere contained high levels of PAN, and Dibb et al. [1997] hypothesized that it was a significant source of $\mathrm{NO}_{\mathrm{x}}$ and subsequently aerosol nitrate to the remote marine boundary layer over the central Pacific.

[28] To assess the regional combustion influence on the $\mathrm{NO}_{\mathrm{y}, \text { sum }}$ distribution over the western Pacific, correlations 

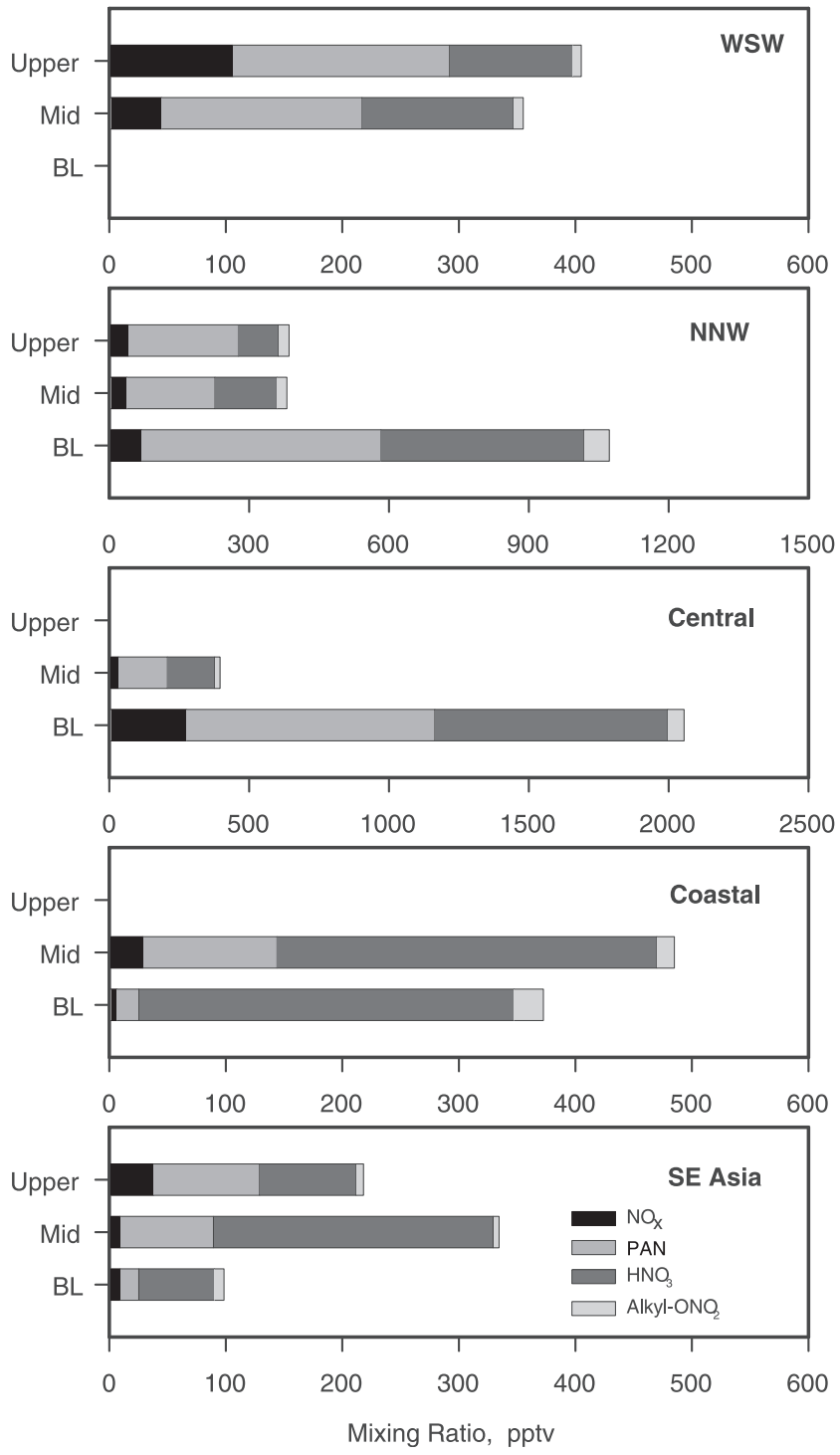

Figure 7. $\mathrm{NO}_{\mathrm{y}}$ budget comparison for the five Asian source regions as a function of altitude $(0-2,2-7$, and $>7 \mathrm{~km}$ ). Median values were used for to construct these budgets.

between $\mathrm{C}_{2} \mathrm{H}_{2}$ and $\mathrm{NO}_{\mathrm{y} \text {,sum }}$ were examined for the five primary Asian source areas defined in Figure 6. These relationships are illustrated in Figure 8. To the best of our understanding, the only source of $\mathrm{C}_{2} \mathrm{H}_{2}$ to the atmosphere is combustion [Singh and Zimmerman, 1992]. $\mathrm{NO}_{\mathrm{y}, \text { sum }}$ and $\mathrm{C}_{2} \mathrm{H}_{2}$ were highly correlated in the SE Asia region, and to a lesser extent in the central and coastal groups. The central group exhibited the best correspondence between $\mathrm{NO}_{\mathrm{y} \text {,sum }}$ and $\mathrm{C}_{2} \mathrm{H}_{2}$, but this was largely driven by the highly polluted nature of the Shanghai plume. There was little or no correlation between these species in the NNW and WSW regions. These two regions are the farthest from the western Pacific, and as such have likely undergone more atmospheric processing than the other groups. The source relationships are consequently more blurred in these datasets. As presented previously, the WSW group also showed the largest mixing ratios of $\mathrm{NO}_{\mathrm{x}}$ above $7 \mathrm{~km}$ of all five source regions. The apparent low correlation with combustion suggests that the $\mathrm{NO}_{\mathrm{x}}$ may be related to stratospheric inputs or be from recycled reactive nitrogen in the upper troposphere. However, why these $\mathrm{NO}_{\mathrm{x}}$ sources would affect only this region is unclear.

[29] To check for stratospheric inputs, correlations were examined between $\mathrm{NO}_{\mathrm{x}}$ and $\mathrm{H}_{2} \mathrm{O}$ vapor, dew point, $\mathrm{O}_{3}, \mathrm{CO}$, and $\mathrm{HNO}_{3}$ in upper troposphere for the WSW group. There was a trend of higher mixing ratios of $\mathrm{NO}_{\mathrm{x}}$ occurring coincidently with low mixing ratios of $\mathrm{H}_{2} \mathrm{O}$ vapor, dew point temperature, and $\mathrm{CO}$ (Figure 9). The highest mixing ratios of NO occurred simultaneously with the lowest dew point temperature and $\mathrm{CO}$ values near $50 \mathrm{ppbv}$, clearly indicative of stratospheric air. Mixing ratios of $\mathrm{HNO}_{3}$ sporadically reached $300-800$ pptv in these same air parcels (not shown). Although these trends lean toward a stratospheric source for the enhanced upper tropospheric $\mathrm{NO}_{\mathrm{x}}$ in the WSW group, other sources such as lightning and combustion cannot be ruled out. Furthermore, it is clear that the air parcels in this upper tropospheric region were influenced by multiple sources, as the relative proportions of $\mathrm{HNO}_{3}$ and PAN to $\mathrm{NO}_{\mathrm{y} \text {,sum }}$ are not consistent with a purely stratospheric source and the intermittent presence of CO mixing ratios in the $100-300$ ppbv range.

[30] $\mathrm{C}_{2} \mathrm{Cl}_{4}$ is released exclusively by urban/industrial processes [Blake et al., 1996], and as such is a good tracer of air parcels influenced by metropolitan areas. In the central and coastal groups there were very general linear relationships between $\mathrm{NO}_{\mathrm{y} \text {,sum }}$ and $\mathrm{C}_{2} \mathrm{Cl}_{4}$, but they were uncorrelated in the other groups (Figure 10). We examined correlations between individual $\mathrm{NO}_{\mathrm{y} \text {,sum }}$ component species and they too showed no clear correspondence with $\mathrm{C}_{2} \mathrm{Cl}_{4}$. However, it appears that the use or release of $\mathrm{C}_{2} \mathrm{Cl}_{4}$ has decreased since the PEM-West B mission. Russo et al. [2003] found that median values of $\mathrm{C}_{2} \mathrm{Cl}_{4}$ were about two-fold less than those observed in the PEM-West B study. This reduced urban/industrial signal probably contributed to the weak correlations between $\mathrm{NO}_{\mathrm{y} \text { sum }}$ and $\mathrm{C}_{2} \mathrm{Cl}_{4}$ during TRACE-P. As indicated by the central group, concentrated urban sources of $\mathrm{C}_{2} \mathrm{Cl}_{4}$ still do exist on the Asian continent. Mixing ratios of $\mathrm{C}_{2} \mathrm{Cl}_{4}$ peaked near $125 \mathrm{pptv}$ when the Shanghai urban plume was sampled over the Yellow Sea.

[31] Biomass burning on the Asian continent is expected to be a large source of $\mathrm{NO}_{\mathrm{y}, \text { sum }}$ [Streets et al., 2003]. These emissions originate from fossil fuel combustion, bio-fuels for space heating and cooking, and agricultural practices. Good tracers of biomass burning emissions include soot carbon, fine aerosol potassium and ammonium, HCN, and $\mathrm{CH}_{3} \mathrm{Cl}$ [Crutzen et al., 1979; Crutzen and Andreae, 1990]. Here we have chosen to use $\mathrm{CH}_{3} \mathrm{Cl}$ due to its availability on a 1-min time basis. The $\mathrm{NO}_{y, \text { sum }}$ correlations with $\mathrm{CH}_{3} \mathrm{Cl}$ over the western Pacific are depicted in Figure 11. The tightest correspondence was observed for the central source region, but it is entirely driven by sampling of the Shanghai plume. There were weak linear correlations in the SE Asia and coastal groups, and none in the NNW and WSW areas. Correlations very similar to those shown in Figure 11 were found using $\mathrm{HCN}$ instead of $\mathrm{CH}_{3} \mathrm{Cl}$ (not shown). This is a bit unexpected, especially for the SE Asian region where extensive biomass burning was indicated by satellite surveying during the TRACE-P time period (available at http:// www.people.fas.harvard.edu/ heald/fires.html). Both the 

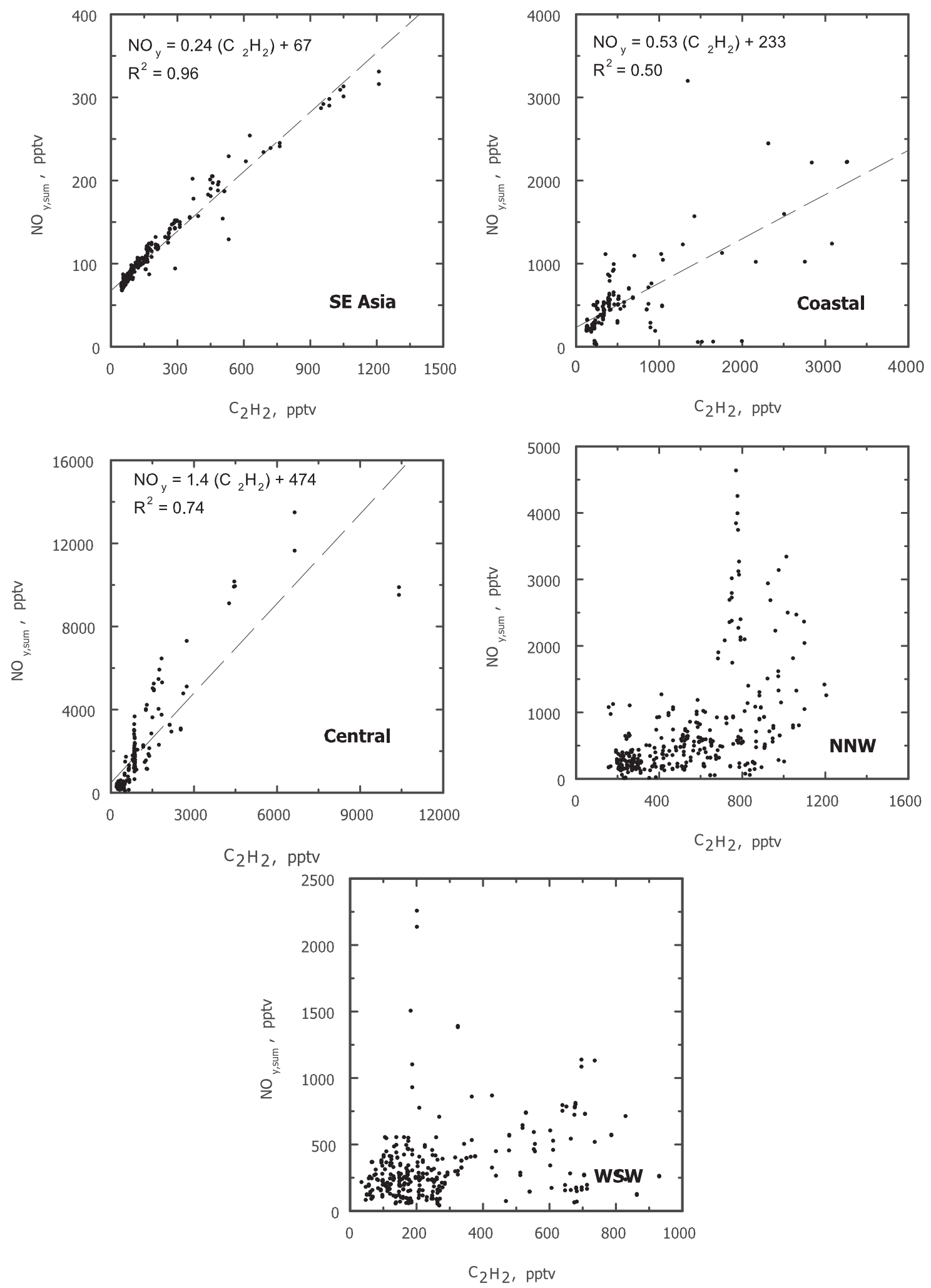

Figure 8. Relationships between $\mathrm{NO}_{\mathrm{y}}$ and $\mathrm{C}_{2} \mathrm{H}_{2}$ for each of the five Asian source regions. $\mathrm{C}_{2} \mathrm{H}_{2}$ is a unique indicator of combustion emissions.

Heald et al. [2003] and Singh et al. [2003] companion papers indicate that $\mathrm{HCN}$ is a better tracer of biomass burning than $\mathrm{CH}_{3} \mathrm{Cl}$ in the free troposphere, but this does not appear to hold up for clearly identifying a biomass burning source for $\mathrm{NO}_{\mathrm{y}, \mathrm{sum}}$. For species with simpler chemical transformations such as $\mathrm{CO}$ or $\mathrm{C}_{2} \mathrm{H}_{2}$, good correlations were found with $\mathrm{HCN}$ in a few limited cases [Russo et al., 2003]. 


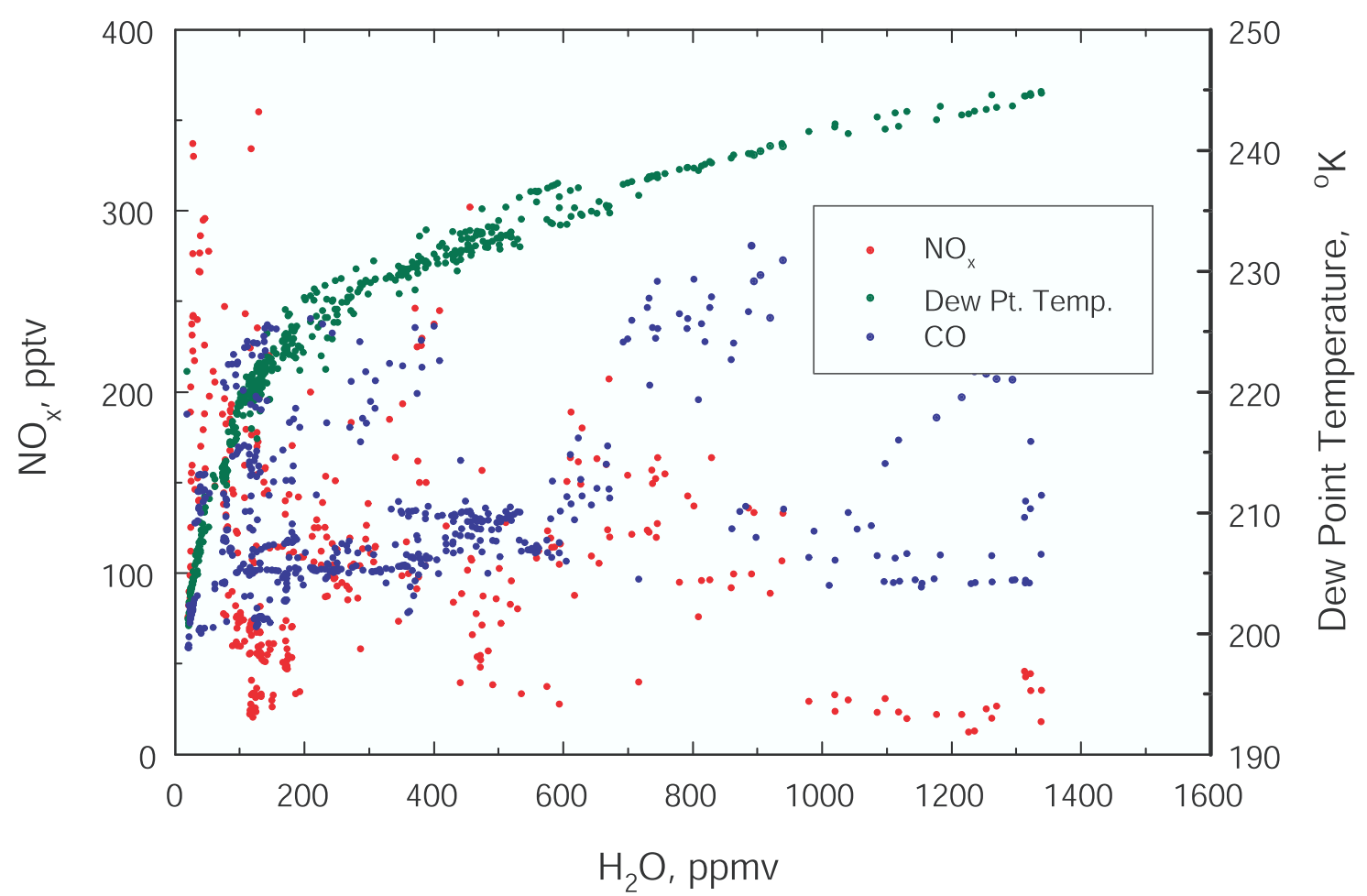

Figure 9. Relationship between $\mathrm{NO}_{\mathrm{x}}$ and $\mathrm{H}_{2} \mathrm{O}$ vapor (red) and dew point temperature (blue) in upper tropospheric air parcels originating over the WSW source region.

[32] Overall, it appears that a unique source signal rarely remained in air parcels advected from over the Asian continent to the western Pacific after extensive processing during transport at the spatial resolution of the present analysis. Both $\mathrm{C}_{2} \mathrm{Cl}_{4}$ and $\mathrm{CH}_{3} \mathrm{Cl}$, which are fairly specific tracers of urban and biomass burning emissions respectively, provided minimal insight to the relative importance of these sources. This may be related to removal of $\mathrm{NO}_{\mathrm{y}}$ during transport eroding the original source signatures and correlations. For urban/industrial tracers we expanded our efforts to include $\mathrm{CH}_{3} \mathrm{CCl}$, Halon-1211, and $\mathrm{CH}_{3} \mathrm{Br}$ (enhanced greatly in Japanese urban areas). None of these improved the source recognition issues. Most distributions were centered commonly around the median mixing ratio of the tracer species employed in the analysis. This result implies that we must rely more than ever on mesoscale modeling results and associated emission inventories to facilitate our understanding of continental scale atmospheric chemistry and intercontinental transport.

\section{Characterization of the Shanghai Plume}

[33] The Shanghai urban plume was sampled during flight 13 at $0.34 \mathrm{~km}$ altitude over the Yellow Sea. The plume was encountered $\sim 100 \mathrm{~km}$ north of Shanghai and sampled along a $300 \mathrm{~km}$ transect over a 38 -min period around midday. The wind speed in the plume averaged $7 \mathrm{~m} \mathrm{~s}^{-1}$, yielding a travel time of 4 hours at the south end to 16 hours at the northernmost point sampled. Thus the plume seemingly sampled air originating in the Shanghai urban center in the late night hours (northern point) and midmorning at the southern end of the transect. Thus it is possible that the peak mixing ratios represent the morning rush hour time period. However, this is pure speculation and we do not know the three-dimensional positioning of the plume and how the DC- 8 transected it. This plume contained the largest mixing ratios of most species, with $\mathrm{O}_{3}$ being one exception, observed during the TRACE-P mission. The plume was a combination of various age air parcels, with the freshest components exhibiting a $\mathrm{C}_{2} \mathrm{H}_{2} / \mathrm{CO}$ ratio of 9.3 and the rest in the 4-6 range (Figure 5). These values suggest a well-defined plume with emissions less than 1 day old.

[34] The large mixing ratios of highly reactive species such as $\mathrm{C}_{2} \mathrm{H}_{4}$ are evidence of the very recent emissions associated with the Shanghai plume (Figure 12). The combustion nature of the plume was captured by the very high levels $\left(\sim 10,000\right.$ pptv) of $\mathrm{C}_{2} \mathrm{H}_{2}$. Mixing ratios of $\mathrm{CO}$ peaked at 1100 ppbv and $392 \mathrm{ppmv}$ for $\mathrm{CO}_{2}$ (not shown). The urban/industrial signature of the plume contained a large ensemble of enhanced volatile organic compounds, including $\mathrm{C}_{2} \mathrm{Cl}_{4}$ and $\mathrm{CH}_{3} \mathrm{Br}$ (Figure 12). Mixing ratios of $\mathrm{CH}_{3} \mathrm{Cl}$ and $\mathrm{HCN}$ exceeded 1600 pptv (3 times background levels), indicating that a strong biomass burning/biofuel component also influenced the chemical composition of the plume (not shown). Li et al. [2003] hypothesized a possible source from residential coal combustion for both $\mathrm{CH}_{3} \mathrm{Cl}$ and for $\mathrm{HCN}$ in this plume.

[35] Since the Shanghai plume appears to represent a large source of reactive nitrogen to the marine boundary layer over the Yellow Sea, we examined its $\mathrm{NO}_{\mathrm{y}, \text { sum }}$ budget in detail. This included examination of the distribution of individual $\mathrm{NO}_{\mathrm{y} \text {,sum }}$ species, plus a breakdown of the seven alkyl nitrate compounds measured by the UCI-NCAR 

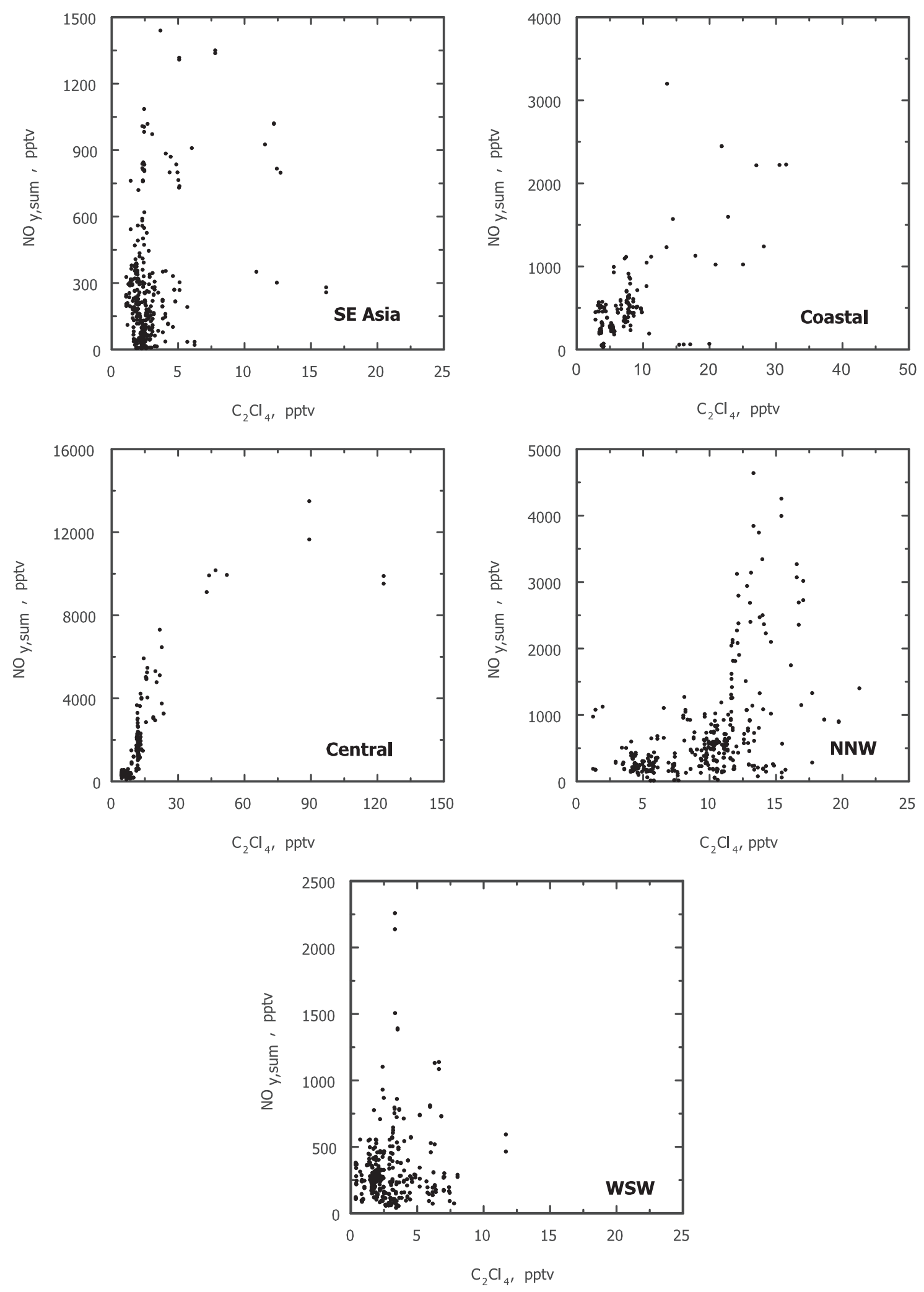

Figure 10. Relationships between $\mathrm{NO}_{\mathrm{y}}$ and $\mathrm{C}_{2} \mathrm{Cl}_{4}$ for each of the five Asian source regions. $\mathrm{C}_{2} \mathrm{Cl}_{4}$ is an indicator of urban/industrial emissions.

groups. These data show that i-propyl and 2-butyl nitrate were the most abundant alkyl nitrate species in this urban/ industrial plume. Their peak mixing ratios were $\sim 70 \mathrm{pptv}$, followed by the pentyl nitrates at $20-25$ pptv. Methyl and ethyl nitrate were among the least abundant, opposite to their distribution over the tropical Pacific where they appear to be released from the surface ocean contributing to the $30-50$ pptv levels typical of the remote marine boundary 

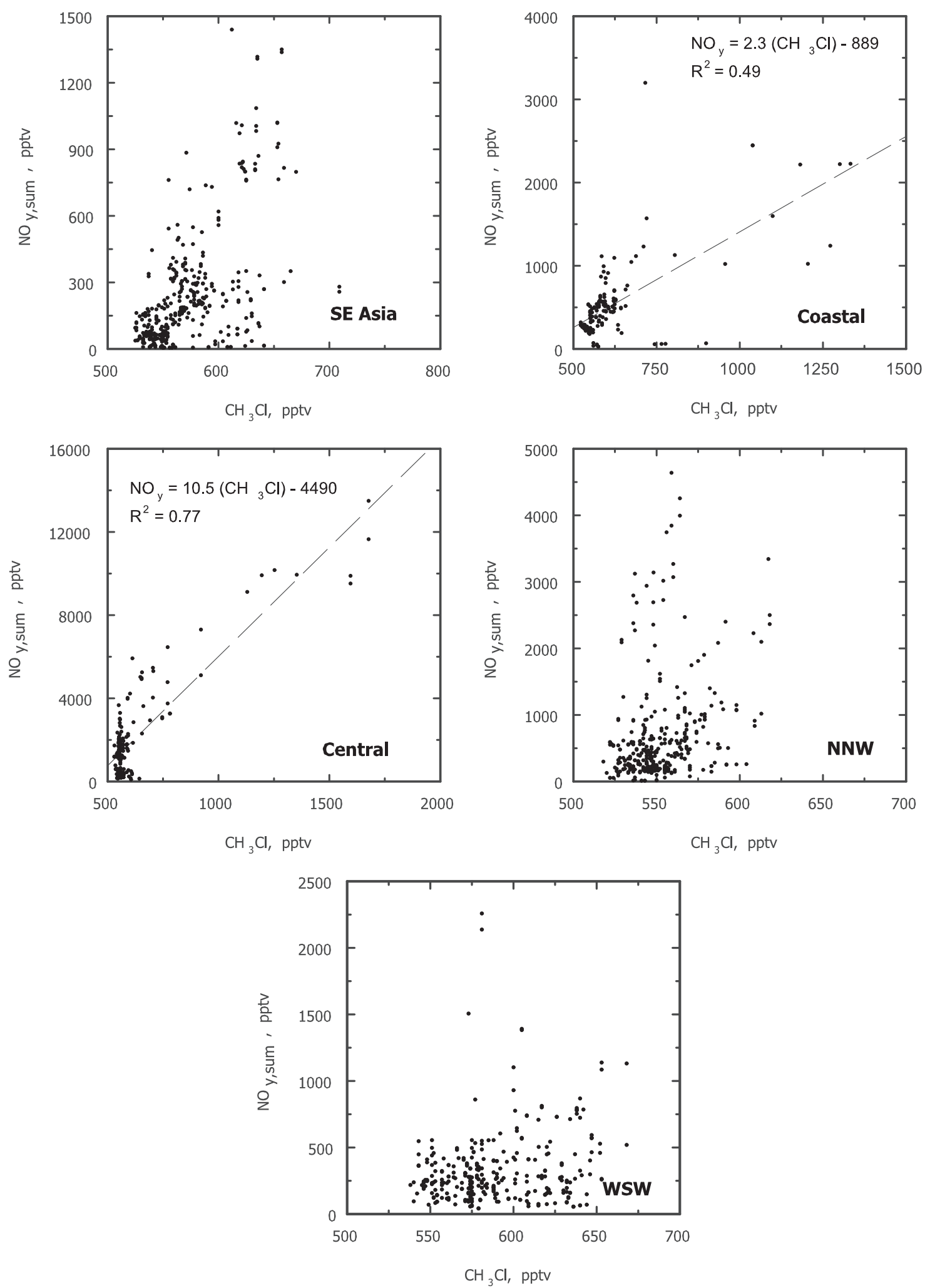

Figure 11. Relationships between $\mathrm{NO}_{\mathrm{y}}$ and $\mathrm{CH}_{3} \mathrm{Cl}$ for each of the five Asian source regions. $\mathrm{CH}_{3} \mathrm{Cl}$ is an indicator of biomass burning emissions.

layer [Talbot et al., 2000; Blake et al., 2003]. Together the alkyl nitrate sum exceeded 200 pptv in the heart of the plume, a very significant amount but still less than $2 \%$ of total $\mathrm{NO}_{\mathrm{y} \text {,sum. }}$.
[36] The distribution of individual $\mathrm{NO}_{\mathrm{y} \text {,sum }}$ species showed the following approximate contributions: $\mathrm{NO}_{\mathrm{x}}$ $(15 \%), \mathrm{HNO}_{3}(53 \%)$, PAN (30\%), and alkyl-ONO $2(2 \%)$. At one point in the marine boundary layer aerosol nitrate 

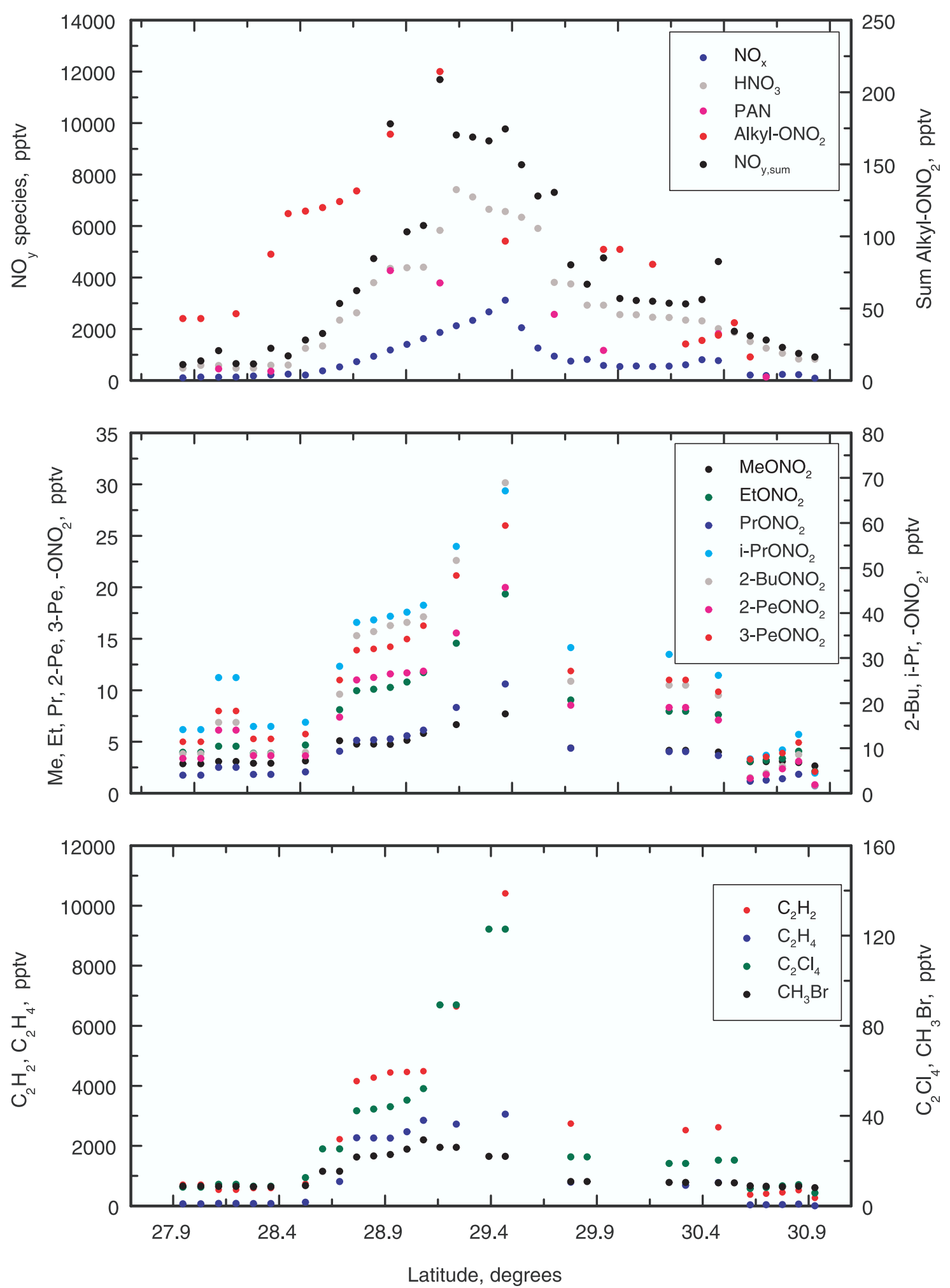

Figure 12. Chemical relationships and breakdown of individual $\mathrm{NO}_{\mathrm{y}}$ species in the Shanghai mega-city plume. The DC-8 flight track was located along a $300 \mathrm{~km}$ north-south longitudinal transect at $125^{\circ} \mathrm{E}$.

reached 13,500 pptv in the plume [Dibb et al., 2003]. Thus it was equal to or greater than total gas phase $\mathrm{NO}_{\mathrm{y} \text {,sum. This }}$ finding suggests that the Shanghai plume contains very large mixing ratios of $\mathrm{HNO}_{3}$ over the Asian continent, but that it is rapidly lost to sea salt aerosols over the ocean. Together the
$\mathrm{HNO}_{3}$ and aerosol nitrate must exceed 20,000 pptv over the Asian continent, with $\mathrm{HNO}_{3}$ likely dominating the phase partitioning. These data indicate that $\mathrm{OH}$ levels in the plume are probably controlled to a large extent by reaction with $\mathrm{NO}_{2}$ to form $\mathrm{HNO}_{3}$. However, detailed measurements are 
required over the Asian continent to confirm such speculations concerning this mega-city urban/industrial plume.

\section{Comparison of TRACE-P With PEM-West B Results}

[37] Owing to rapid industrialization on the Asian continent, it is of great interest to examine changes in tropospheric chemistry over the western Pacific during the past decade. Since PEM-West B was conducted during the same monthly time frame in 1994 that TRACE-P covered in 2001, direct meaningful comparisons are possible. In addition, many of the species were measured by the same investigator groups during both missions, minimizing measurement biases.

[38] Russo et al. [2003] found few changes in the distributions and mixing ratios of a large suite of trace gases. One exception to this was $\mathrm{O}_{3}$, which appears to have increased by 10-20 ppbv throughout the western Pacific. There was a very significant increase in the mixing ratios of water-soluble aerosol species during TRACE-P compared to PEM-West B [Dibb et al., 2003]. It is difficult to access how much of the 2-5 fold increases were due to emissions compared to other confounding factors such as variations in the degree of precipitation scavenging.

[39] For the comparisons we used summary statistics for the PEM-West B period reported by Talbot et al. [1997a]. The PEM-West B data were broken into two groups, continental north and south, divided by a geographic separation at $20^{\circ} \mathrm{N}$. We thus compared the continental north group with the TRACE-P coastal, central, and NNW groups and the continental south region with the SE Asia group. The WSW group was not used in these comparisons since it overlaps significantly with both PEM-West B source regions. The values of $\mathrm{NO}_{\mathrm{y} \text {,sum }}$ for PEM-West $\mathrm{B}$ were taken from Talbot et al. [1997a, 1997b].

[40] Tables 1 and 2 contain a summary of $\mathrm{NO}_{\mathrm{y}, \text { sum }}$ species comparisons for the two western Pacific missions. In the boundary layer for the northern groupings median mixing ratios of $\mathrm{HNO}_{3}$ and PAN were 2-5 times higher during TRACE-P compared to PEM-West B. An exception was for PAN in the coastal group. Although most of the differences in mean values are statistically significant (t-test, $\mathrm{P}=0.05$ ), the maximum values are relatively similar. The comparisons for $\mathrm{NO}_{\mathrm{y} \text {,sum }}$ are not significantly different except for the central group at $0-2 \mathrm{~km}$ altitude where they were much greater than the PEM-West $\mathrm{B}$ results $(\mathrm{P}=0.05)$. Comparisons for the middle and upper troposphere revealed a remarkable similarity over the 7 year period between the missions. The only significant difference was for $\mathrm{HNO}_{3}$ in the coastal group where the mean values for TRACE-P were a factor of 2 higher than in PEM-West $\mathrm{B}(\mathrm{P}=0.05)$.

[41] Comparisons of the continental south group with the TRACE-P SE Asia group showed that differences existed but they did not vary in a systematic manner. In the boundary layer median mixing ratios of $\mathrm{HNO}_{3}$ and $\mathrm{NO}_{\mathrm{y}, \text { sum }}$ were eight-fold and six-fold lower during TRACE-P, respectively. This may be due to the fact that during PEM-West $\mathrm{B}$ relatively few data were obtained in the continental south region [Talbot et al., 1997b]. We clearly did not get a good statistical sampling of air parcels in 1994, so the results are
Table 1. TRACE-P Nitrogen Budget Summary Statistics

\begin{tabular}{|c|c|c|c|c|c|c|}
\hline Source Region & & $\mathrm{NO}_{\mathrm{x}}$ & PAN & $\mathrm{HNO}_{3}$ & $\begin{array}{c}\Sigma \text { Alkyl- } \\
\mathrm{ONO}_{2}\end{array}$ & $\mathrm{NO}_{\mathrm{y}, \text { sum }}{ }^{\mathrm{a}}$ \\
\hline \multicolumn{7}{|c|}{$N N W$} \\
\hline \multirow[t]{5}{*}{$0-2 \mathrm{~km}$} & mean & 351 & 505 & 447 & 56 & 940 \\
\hline & stdev. & 695 & 326 & 195 & 12 & 881 \\
\hline & median & 69 & 514 & 436 & 54 & 597 \\
\hline & $\min$ & 0.79 & 1.3 & 63 & 26 & 12 \\
\hline & $\max$ & 3507 & 1422 & 1198 & 89 & 5115 \\
\hline \multirow{5}{*}{$2-7 \mathrm{~km}$} & mean & 68 & 292 & 197 & 25 & 388 \\
\hline & stdev. & 79 & 244 & 243 & 15 & 413 \\
\hline & median & 38 & 189 & 133 & 21 & 255 \\
\hline & $\min$ & 5.1 & 89 & 49 & 7.1 & 59 \\
\hline & $\max$ & 688 & 998 & 2028 & 71 & 3341 \\
\hline \multirow{5}{*}{$>7 \mathrm{~km}$} & mean & 132 & 282 & 152 & 21 & 416 \\
\hline & stdev. & 172 & 157 & 191 & 15 & 327 \\
\hline & median & 41 & 236 & 86 & 23 & 295 \\
\hline & $\min$ & 8.3 & 80 & 41 & 3.6 & 60 \\
\hline & $\max$ & 557 & 550 & 1030 & 50 & 1123 \\
\hline \multicolumn{7}{|c|}{ Central } \\
\hline \multirow{5}{*}{$0-2 \mathrm{~km}$} & mean & 395 & 1225 & 1323 & 69 & 2422 \\
\hline & stdev. & 437 & 1014 & 1293 & 33 & 2248 \\
\hline & median & 276 & 888 & 833 & 58 & 1723 \\
\hline & $\min$ & 25 & 2.4 & 222 & 25 & 222 \\
\hline & $\max$ & 3111 & 4264 & 7412 & 214 & 13487 \\
\hline \multirow[t]{5}{*}{$2-7 \mathrm{~km}$} & mean & 48 & 194 & 202 & 20 & 297 \\
\hline & stdev. & 44 & 69 & 110 & 5.1 & 150 \\
\hline & median & 33 & 175 & 169 & 19 & 276 \\
\hline & $\min$ & 1.1 & 118 & 106 & 9.1 & 65 \\
\hline & $\max$ & 205 & 364 & 938 & 30 & 938 \\
\hline \multicolumn{7}{|c|}{ Coastal } \\
\hline \multirow{5}{*}{$0-2 \mathrm{~km}$} & mean & 34 & 207 & 439 & 11 & 541 \\
\hline & stdev. & 89 & 336 & 365 & 20 & 525 \\
\hline & median & 6.5 & 19 & 322 & 25 & 386 \\
\hline & $\min$ & 0.52 & 1.3 & 128 & 10 & 56 \\
\hline & $\max$ & 581 & 1065 & 2120 & 104 & 3267 \\
\hline \multirow[t]{5}{*}{$2-7 \mathrm{~km}$} & mean & 40 & 142 & 439 & 17 & 431 \\
\hline & stdev. & 42 & 126 & 365 & 7.9 & 260 \\
\hline & median & 29 & 115 & 326 & 13 & 475 \\
\hline & $\min$ & 6.3 & 15 & 135 & 10 & 24 \\
\hline & $\max$ & 247 & 412 & 876 & 33 & 1096 \\
\hline \multicolumn{7}{|c|}{ SE Asia } \\
\hline \multirow[t]{5}{*}{$0-2 \mathrm{~km}$} & mean & 81 & 46 & 139 & 3.7 & 218 \\
\hline & stdev. & 187 & 51 & 217 & 4.3 & 273 \\
\hline & median & 9.4 & 16 & 65 & 8.1 & 91 \\
\hline & $\min$ & 9.0 & 2.7 & 12 & 3.2 & 6.4 \\
\hline & $\max$ & 836 & 237 & 884 & 19 & 1158 \\
\hline \multirow[t]{5}{*}{$2.7 \mathrm{~km}$} & mean & 81 & 157 & 338 & 10 & 384 \\
\hline & stdev. & 187 & 190 & 233 & 11 & 330 \\
\hline & median & 9.4 & 80 & 240 & 5.4 & 306 \\
\hline & $\min$ & 1.1 & 8.4 & 100 & 3.1 & 5.0 \\
\hline & $\max$ & 836 & 660 & 1352 & 45 & 1439 \\
\hline $7-12.5 \mathrm{~km}$ & mean & 39 & 81 & 102 & 3.2 & 174 \\
\hline & stdev. & 32 & 58 & 78 & 4.2 & 108 \\
\hline & median & 38 & 91 & 83 & 6.2 & 162 \\
\hline & $\min$ & 1.3 & 6.2 & 3.0 & 2.3 & 5.8 \\
\hline & $\max$ & 139 & 238 & 320 & 20 & 495 \\
\hline & & & $S W$ & & & \\
\hline $2-7 \mathrm{~km}$ & mean & 70 & 172 & 137 & 8.8 & 240 \\
\hline & stdev. & 46 & 62 & 47 & 2.8 & 118 \\
\hline & median & 45 & 172 & 130 & 8.3 & 211 \\
\hline & $\min$ & 7.8 & 78 & 81 & 5.0 & 81 \\
\hline & $\max$ & 154 & 311 & 306 & 14 & 569 \\
\hline $7-12.5 \mathrm{~km}$ & mean & 112 & 258 & 138 & 8.5 & 309 \\
\hline & stdev. & 66 & 182 & 170 & 5.1 & 249 \\
\hline & median & 106 & 186 & 106 & 7.1 & 247 \\
\hline & $\min$ & 12 & 30 & 25 & 1.8 & 3.5 \\
\hline & $\max$ & 354 & 699 & 1987 & 23 & 2257 \\
\hline
\end{tabular}

${ }^{a}$ Sum of the individual species (see text). 
Table 2. PEM-WEST B Nitrogen Budget Summary Statistics

\begin{tabular}{|c|c|c|c|c|c|c|}
\hline \multicolumn{2}{|c|}{ Source Region } & $\mathrm{NO}$ & PAN & $\mathrm{HNO}_{3}$ & $\Sigma$ Alkyl-ONO ${ }_{2}$ & $\mathrm{NO}_{\mathrm{y}, \text { sum }^{\mathrm{a}}}$ \\
\hline \multicolumn{7}{|c|}{ Continental North } \\
\hline \multirow[t]{5}{*}{$0-2 \mathrm{~km}$} & mean & 31 & 559 & 617 & NA & 1084 \\
\hline & stdev. & 67 & 434 & 1263 & NA & 1587 \\
\hline & median & 18 & 134 & 229 & NA & 624 \\
\hline & $\min$ & 3.1 & 54 & 30 & NA & 123 \\
\hline & $\max$ & 937 & 2187 & 6596 & NA & 10243 \\
\hline \multirow[t]{5}{*}{$2-7 \mathrm{~km}$} & mean & 16 & 289 & 168 & NA & 449 \\
\hline & stdev. & 18 & 190 & 166 & NA & 305 \\
\hline & median & 13 & 108 & 126 & NA & 406 \\
\hline & $\min$ & 2.6 & 1.7 & 37 & NA & 64 \\
\hline & $\max$ & 568 & 885 & 1115 & NA & 1923 \\
\hline \multirow[t]{5}{*}{$>7 \mathrm{~km}$} & mean & 49 & 177 & 166 & NA & 473 \\
\hline & stdev. & 68 & 164 & 69 & NA & 208 \\
\hline & median & 39 & 98 & 146 & NA & 449 \\
\hline & $\min$ & 7.4 & 20 & 62 & NA & 153 \\
\hline & $\max$ & 833 & 965 & 389 & NA & 1033 \\
\hline \multicolumn{7}{|c|}{ Continental South } \\
\hline \multirow[t]{5}{*}{$0-2 \mathrm{~km}$} & mean & 13 & 78 & 615 & NA & 941 \\
\hline & stdev. & 7.8 & 82 & 316 & NA & 1114 \\
\hline & median & 6.8 & 6.4 & 548 & NA & 721 \\
\hline & $\min$ & 4.6 & 6.4 & 219 & NA & 159 \\
\hline & $\max$ & 40 & 247 & 1275 & NA & 7029 \\
\hline \multirow[t]{5}{*}{$2-7 \mathrm{~km}$} & mean & 15 & 35 & 455 & NA & 279 \\
\hline & stdev. & 7.8 & 22 & 344 & NA & 206 \\
\hline & median & 17 & 13 & 421 & NA & 257 \\
\hline & $\min$ & 4.5 & 5.4 & 55 & NA & 75 \\
\hline & $\max$ & 30 & 68 & 1225 & NA & 868 \\
\hline \multirow[t]{5}{*}{$>7 \mathrm{~km}$} & mean & 57 & 57 & 124 & NA & 234 \\
\hline & stdev. & 34 & 28 & 47 & NA & 132 \\
\hline & median & 56 & 38 & 122 & NA & 243 \\
\hline & $\min$ & 7.9 & 8.8 & 55 & NA & 68 \\
\hline & $\max$ & 339 & 149 & 279 & NA & 540 \\
\hline
\end{tabular}

${ }^{\mathrm{a}} \mathrm{Sum}$ of the individual species [Talbot et al., 1997a, 1997b].

unlikely to be representative of that region. It may be fortuitous for the previous reason that the middle and upper tropospheric data are similar for both missions. Nevertheless, it appears that in general the $\mathrm{NO}_{\mathrm{y}, \text { sum }}$ loading above the boundary layer has been affected minimally by increasing emissions on the Asian continent over the last 7 years. The data show that the biggest changes and influences were in the boundary layer. Liu et al. [2003] hypothesize that the higher mixing ratios of water-soluble aerosol in TRACE-P relative to PEM-West B [Dibb et al., 2003] together with higher $\mathrm{NO}_{\mathrm{y}, \text { sum }}$ in the boundary layer, may reflect stronger boundary layer outflow during TRACE-P because of more frequent frontal passages. Such interannual variability in the western Pacific region requires careful documentation to distinguish it from response to changes in emission sources.

\section{Summary}

[42] We presented the general distributions of $\mathrm{NO}_{\mathrm{y}, \text { sum }}$ and individual $\mathrm{NO}_{\mathrm{y} \text {,sum }}$ species over the western Pacific during the TRACE-P study period of February-March 2001. In general, $\mathrm{NO}_{\mathrm{y}, \text { sum }}$ was dominated by $\mathrm{HNO}_{3}$ and PAN, while $\mathrm{NO}_{\mathrm{x}}$ mixing ratios were commonly $<100 \mathrm{pptv}$ except in plumes where they exceeded 1000 pptv on a few occasions. There was a significant combustion influence over the western Pacific, as evidenced by the distributions of $\mathrm{CO}$ and $\mathrm{C}_{2} \mathrm{H}_{2}$. Correlations of $\mathrm{NO}_{y}$,sum with an urban tracer such as $\mathrm{C}_{2} \mathrm{Cl}_{4}$ and $\mathrm{CH}_{3} \mathrm{Cl}$ for biomass burning were not well defined in most cases.
[43] The distribution of the ratio $\mathrm{C}_{2} \mathrm{H}_{2} / \mathrm{CO}$ was striking, showing values in the middle to upper troposphere that mimicked the boundary layer and ones that support a scenario of rapid advective transport of continent emissions across the Pacific to at least $150^{\circ} \mathrm{E}$. These findings suggest that extensive and rapid frontal uplifting and vertical transport is operating continuously over the Asian continent combined with extensive westerly transport of pollutants at all altitudes. This result helps explain the blurred correlations observed between $\mathrm{NO}_{\mathrm{y} \text {,sum }}$ and $\mathrm{CO}$ or $\mathrm{O}_{3}$. Such continuous intermixing of air parcels of various ages and processing would lead directly to the very complex distributions and relationships that we observed for $\mathrm{NO}_{\mathrm{y}, \text { sum }}, \mathrm{CO}$, and $\mathrm{O}_{3}$. In addition, removal of $\mathrm{NO}_{\mathrm{y}}$ during transport would further distort source signatures and species intercorrelations.

[44] On one occasion the Shanghai mega-city plume was characterized during a flight over the Yellow Sea. The plume was intercepted at $0.34 \mathrm{~km}$ altitude and exhibited peak mixing ratios of more than 10,000 pptv $\mathrm{C}_{2} \mathrm{H}_{2}, 3,000$ pptv $\mathrm{C}_{2} \mathrm{H}_{4}, 12,000 \mathrm{NO}_{\mathrm{y} \text {,sum }}, 8,000$ pptv $\mathrm{HNO}_{3}$, and 30 pptv $\mathrm{CH}_{3} \mathrm{Br} . \mathrm{C}_{1}-\mathrm{C}_{5}$ alkyl nitrates totaled 100-200 pptv, being dominated by $2-\mathrm{BuONO}_{2}$ and i-PrONO $\mathrm{H}_{2}$. Our results suggest that the Shanghai plume represents a large source of reactive nitrogen to the marine boundary layer over the Yellow Sea.

[45] Comparison of results between the earlier PEM-West $\mathrm{B}$ mission and the recent TRACE-P campaign show remarkable similarities in tropospheric chemistry. This was most evident in the middle and upper troposphere where $\mathrm{NO}_{\mathrm{y} \text {,sum }}$ loadings appear to have been affected minimally by increasing emissions on the Asian continent over the last 7 years. However, significant increases in the mixing ratios of $\mathrm{NO}_{\mathrm{y} \text {,sum }}$ species were readily apparent in the boundary layer.

[46] Acknowledgments. We appreciate the support provided by the DC-8 flight and ground crews at the NASA Dryden Flight Research Center. This research was supported by the NASA Global Tropospheric Chemistry program in the Office of Earth Science.

\section{References}

Bernsten, T. K., and S. Karlsdottir, Influence of Asian emissions on the composition of air reaching the North Western United States, Geophys. Res. Lett., 26, 2171-2174, 1999.

Blake, D. R., T.-Y. Chen, T. W. Smith Jr., C. J.-L Wang, O. W. Wingenter, F. S. Rowland, and E. W. Mayer, Three dimensional distribution of NMHCs and halocarbons over the northwestern Pacific during the 1991 Pacific Exploratory Mission (PEM-West A), J. Geophys. Res., 101, 1763-1778, 1996.

Blake, N. J., D. R. Blake, A. L. Swanson, E. Atlas, F. Flocke, and F. S. Rowland, Latitudinal, vertical, and seasonal variations in $C_{1}-C_{4}$ alkyl nitrates in the troposphere over the Pacific Ocean during PEM-Tropics A and B: Oceanic and continental sources, J. Geophys, Res., 108(D2), 8242, doi:10.1029/2001JD001444, 2003.

Bradshaw, J., et al., Photofragmentation two-photon laser-induced detection of $\mathrm{NO}_{2}$ and NO: Comparison of measurements with model results based on airborne observations during PEM-Tropics A, Geophys. Res., Lett., 26, 471-474, 1999.

Brune, W. H., I. C. Faloona, D. Tan, A. J. Weinheimer, T. Campos, B. A. Ridley, S. A. Vay, J. E. Collins, G. W. Sachse, L. Jaegle, and D. J. Jacob, Airborne in-situ $\mathrm{OH}$ and $\mathrm{HO}_{2}$ observations in the cloud-free troposphere and lower stratosphere during SUCCESS, Geophys. Res. Lett., 25, $1701-$ 1704, 1998.

Colman, J. J., A. L. Swanson, S. Meinarde, and D. R. Blake, Description of the analysis of a wide range of volatile organic compounds in whole air samples collected during PEM-Tropics A and B, Anal. Chem., 73, 37233731, 2001.

Crutzen, P. J., and M. O. Andreae, Biomass burning in the tropics: Impact on atmospheric chemistry and biogeochemical cycles, Science, 250, $1669-1678,1990$. 
Crutzen, P. J., L. E. Heidt, J. P. Krasnec, W. H. Pollock, and W. Seiler, Biomass burning as a source of atmospheric gases $\mathrm{CO}, \mathrm{H}_{2}, \mathrm{~N}_{2} \mathrm{O}, \mathrm{NO}$, $\mathrm{CH}_{3} \mathrm{Cl}$, and COS, Nature, 282, 253-256, 1979.

Dibb, J. E., R. W. Talbot, B. L. Lefer, and E. Scheuer, Distributions of beryllium-7 and lead-210 over the western Pacific: PEM-West B, February-March 1994, J. Geophys. Res., 102, 28,287-28,302, 1997.

Dibb, J. E., R. W. Talbot, E. Scheuer, G. Seid, M. Avery, and H. Singh, Aerosol chemical composition in Asian continental outflow during TRACE-P: Comparison to PEM-West B, J. Geophys. Res., 108(D21), 8815, doi:10.1029/2002JD003111, in press, 2003.

Eisele, F. L., et al., Informal instrument intercomparison summary of selected atmospheric species on the NASA DC-8 and P-3 during TRACE-P, J. Geophys. Res., 108(D20), 8791, doi:10.1029/ 2002JD003167, in press, 2003

Emmons, L. K., D. A. Hauglustaine, J.-F. Muller, M. A. Carroll, G. P. Brasseur, D. Brunner, J. Staehelin, V. Thouret, and A. Marenco, Data composites of airborne observations of tropospheric ozone and its precursors, J. Geophys. Res., 105, 20,497-20,538, 2000.

Fuelberg, H., C. M. Kiley, J. R. Hannan, D. J. Westberg, M. A. Avery, and R. E. Newell, Atmospheric transport during the Transport and Chemical Evolution over the Pacific (TRACE-P) experiment, J. Geophys. Res., 108(D20), 8782, doi:10.1029/2002JD003092, in press, 2003.

Heald, C. L., D. J. Jacob, P. I. Palmer, M. J. Evans, G. W. Sachse, H. B. Singh, and D. R. Blake, Biomass burning emission inventory with daily resolution: Application to aircraft observations of Asian outflow, J. Geophys. Res., 108(D21), 8811, doi:10.1029/2002JD003082, in press, 2003

Hoell, J. M., D. D. Davis, S. C. Liu, R. Newell, M. Shipman, H. Akimoto, R. J. McNeal, R. J. Bendura, and J. W. Drewery, Pacific Exploratory Mission-West A (PEM-West A): September-October 1991, J. Geophys. Res., 101, 1641-1653, 1996.

Hoell, J. M., D. D. Davis, S. C. Liu, R. E. Newell, H. Akimoto, R. J. McNeal, and R. J. Bendura, The Pacific Exploratory Mission-West Phase B: February-March, 1994, J. Geophys. Res., 102, 28,233-28,239, 1997.

Jacob, D. J., J. A. Logan, and P. P. Murti, Effect of rising Asian emissions on surface ozone in the United States, Geophys. Res. Lett., 26, $2175-$ 2178, 1999.

Jacob, D. J., J. H. Crawford, M. M. Kleb, V. E. Connors, R. J. Bendura, J. L. Raper, G. W. Sachse, J. C. Gille, L. Emmons, and C. L. Heald, The Transport and Chemical Evolution over the Pacific (TRACE-P) aircraft mission: Design, execution, and first results, J. Geophys. Res., 108(D20), 8781, doi:10.1029/2002JD003276, in press, 2003.

Jordan, C. E., et al., Chemical and physical properties of bulk aerosols within four sectors observed during TRACE-P, J. Geophys. Res., 108(D21), 8813, doi:10.1029/2002JD003337, in press, 2003.

Koike, M., Y. Kondo, S. Kawakami, H. Nakajima, G. L Gregory, G. W. Sachse, H. B. Singh, E. V. Browell, J. T. Merrill, and R. E. Newell, Reactive nitrogen and its correlation with $\mathrm{O}_{3}$ and $\mathrm{CO}$ over the Pacific in winter and early spring, J. Geophys. Res., 102, 28,385-28,404, 1997.

Li, Q., D. J. Jacob, R. M. Yantosca, C. L. Heald, H. B. Singh, M. Koike, Y. Zhao, G. W. Sachse, and D. G. Streets, A global 3-D model evaluation of the atmospheric budgets of $\mathrm{HCN}$ and $\mathrm{CH}_{3} \mathrm{CN}$ : Constraints from aircraft measurements over the western Pacific, J. Geophys. Res., 108(D21) 8827, doi:10.1029/2002JD003075, in press, 2003.

Liu, H., D. J. Jacob, I. Bey, M. Yantosca, B. N. Duncan, and G. W. Sachse, Transport pathways for Asian combustion outflow over the Pacific: Interannual and seasonal variations, J. Geophys. Res., 108(D20), 8786, doi:10.1029/2002JD003102, in press, 2003

Russo, R., et al., Chemical composition of Asian continental outflow over the western Pacific: Results from TRACE-P, J. Geophys. Res., 108(D20), 8804, doi:10.1029/2002JD003184, in press, 2003.
Sandholm, S., J. D. Bradshaw, K. S. Dorris, M. O. Rogers, and D. D. Davis, An airborne-compatible photofragmentation two-photon laser-induced fluorescence instrument for measuring background tropospheric NO, $\mathrm{NO}_{x}$, and $\mathrm{NO}_{2}, J$. Geophys. Res., 95, 10,155-10,161, 1990.

Singh, H. B., and P. B. Zimmerman, Atmospheric distribution and sources of nonmethane hydrocarbons, in Gaseous Pollutants: Characterization and Cycling, John Wiley, New York, 1992.

Singh, H., Y. Chen, A Staudt, D. Jacob, D. Blake, B. Heikes, and J. Snow, Evidence from the Pacific troposphere for large global sources of oxygenated organic compounds, Nature, 410, 1078-1081, 2001.

Singh, H. B., et al., In situ measurements of $\mathrm{HCN}$ and $\mathrm{CH}_{3} \mathrm{CN}$ in the Pacific troposphere: Sources, sinks, and comparisions with spectroscopic observations, J. Geophys. Res., 108(D20), 8789, doi:10.1029/2002JD003006, in press, 2003

Streets, D. G., et al., A year-2000 inventory of gaseous and primary aerosol emissions in Asia to support TRACE-P modeling and analysis, J. Geophys. Res., 108(D21), 8809, doi:10.1029/2002JD003093, in press, 2003. Talbot, R. W., et al., Chemical characteristics of continental outflow from Asia to the troposphere over the western Pacific Ocean during September-October 1991: Results from PEM-West A, J. Geophys. Res., 101, $1713-1725,1996$.

Talbot, R. W., et al., Chemical characteristics of continental outflow from Asia to the troposphere over the western Pacific Ocean during FebruaryMarch 1994: Results from PEM-West B, J. Geophys. Res., 102, 28,25528,274, 1997a.

Talbot, R. W., et al., Large-scale distributions of tropospheric nitric, formic, and acetic acids over the western Pacific basin during wintertime, J. Geophys. Res., 102, 28,303-28,313, 1997b.

Talbot, R. W., et al., Reactive nitrogen budget during the NASA SONEX mission, Geophys. Res. Lett., 26, 3057-3060, 1999.

Talbot, R. W., J. E. Dibb, E. M. Scheuer, J. D. Bradshaw, S. T. Sandholm, H. B. Singh, D. R. Blake, N. J. Blake, E. Atlas, and F. Flocke, Tropospheric reactive odd nitrogen over the South Pacific in austral springtime, J. Geophys. Res., 105, 6681-6694, 2000

U.S. Department of Energy, International Energy Outlook (IEO), Energy Inf. Admin., Washington, D. C., 1997.(Available at http://www.eia.doe. gov/oiaf/ieo97)

Van Aardenne, J. A., G. A. Carmichael, H. Levy II, D. Streets, and L. Hordijk, Anthropogenic $\mathrm{NO}_{\mathrm{x}}$ emissions in Asia in the period 19902020, Atmos. Environ., 33, 633-646, 1999.

Zhang, Y., Synoptic Meteorology and Climate, pp. 600-601, Meteorology Press, Beijing, China, 1992.

E. Atlas, National Center for Atmospheric Research, Boulder, CO 80305, USA. (atlas@acd.ucar.edu)

M. Avery, C. Jordan, and G. Sachse, NASA Langley Research Center, Hampton, VA 23665, USA. (m.a.avery@larc.nasa.gov; c.e.jordan@larc. nasa.gov; g.w.sachse@larc.nasa.gov)

D. Blake and N. Blake, University of California, Irvine, Irvine, CA 92716, USA. (drblake@uci.edu; nblake@uci.edu)

J. Dibb, R. Russo, E. Scheuer, G. Seid, and R. Talbot, University of New Hampshire, Durham, NH 03820, USA. (jack.dibb@unh.edu; rsrusso@cisunix.unh.edu; eric.scheuer@unh.edu; gseid@mail.kgi.edu; robert.talbot@unh.edu)

S. Sandholm, H. Singh, and D. Tan, Georgia Institute of Technology, Atlanta, GA 30332, USA. (sts@minitower.eas.gatech.edu; hanwat.b. singh@nasa.gov; dtan@eas.gatech.edu) 